Federal Reserve Bank of Minneapolis Research Department

\title{
Banknote Prices in the United States Prior to 1860*
}

\author{
Warren E. Weber \\ Working Paper 629 \\ October 2003 \\ Preliminary and Incomplete
}

\begin{abstract}
This paper examines the pricing of statebank notes prior to 1860 using data on the discounts on these notes as quoted in New York, Philadelphia, Cincinnati, and Cleveland. The study is organized around determining whether these banknotes were priced consistent with their expected net redemption value. It finds a bank's notes had higher prices when it was redeeming it notes for specie than when is was suspended. However, although prices generally varied inversely with redemption costs, the relationship was not tight and persistent arbitrage opportunities existed.
\end{abstract}

*I am indebted to participants at seminars at the Federal Reserve Bank of Minneapolis, the Central Bank Institute at the Federal Reserve Bank of Cleveland, the University of Indiana, and the University of Kentucky for helpful comments on an earlier version of this paper. The views expressed herein are those of the author and not necessarily those of the Federal Reserve Bank of Minneapolis or the Federal Reserve System. 
The United States had only one bank when it won independence from Great Britain in 1786. This did not remain the situation for long, however. By 1800, close to 30 banks were in existence, and over 250 more came into existence in the next twenty years. The rapid growth in the number of banks continued over the next two decades, and by 1840 the country had approximately 600 banks. Although the number of banks fell during the 1840s, there was a huge expansion in the number of banks in the 1850s. The country had almost 1400 banks in 1860, just before the start of the Civil War.

Prior to 1863 , the only way to get permission to operate a bank was to obtain a state charter. ${ }^{1}$ Under these charters, banks were permitted to issue banknotes - dollar denominated promises to pay specie to the bearer on demand. ${ }^{2}$ Notes were distinguishable by the issuing bank, and virtually all banks issued them. Banknotes were almost always at least $\$ 1$ in denomination, and in many cases banks were restricted to issuing notes no smaller that $\$ 5$. To give these denominations some perspective, some typical prices in 1850 were ...

Banknotes circulated hand-to-hand and were the largest component of the currency in circulation during the period. Consequently, throughout the antebellum period there were large numbers of distinct currencies in circulation in the country.

There are two general facts about the rates at which these various currencies exchanged. First, even though all banknotes were denominated in dollars, the notes of different banks did not exchange with each other at par. Second, the exchange rates between the notes

\footnotetext{
${ }^{1}$ There were two exceptions: The (First) Bank of the United States, 1801-1811 and the (Second) Bank of the United States, 1816 - 1836, which were chartered by the federal government. Although these banks issued notes, I do not consider them in this paper.

${ }^{2}$ During this period, a dollar was defined to be governmentally minted coin containing a specified amount of silver (3xx. grains). Large denomination coins were made of gold and contained specified amounts of that metal.
} 
of different banks were not constant over time. These facts are known from contemporary sources. Specialized publications listed the rates of discount or premium on the notes of banks throughout the country in terms of notes of banks of some city, usually the location of the publication. These "Bank Note Reporters and Counterfeit Detectors," as they were generally known because many also contained lists of known counterfeits, were usually published by or in collaboration with a broker in a particular city. ${ }^{3}$ Also, many newspapers published "Bank Note Tables" that contained similar information on note prices.

The existence of a large number of currencies circulating at floating exchange rates has led many to conclude that the banking arrangements during this period were an impediment to trade and economic growth. This was true of some contemporary observers. For example, Senator John Sherman of Ohio used the following quote from the London Times in a speech on February 10, 1863, to advocate passage of the National Currency Act:

By the want of a paper currency that would be taken in every State of the Union at its nominal value the Americans have suffered severely. The different States were, as to their bank notes, so many foreign countries, each refusing the paper of the others, except at continually varying rates of discount.... Only adepts and regular money-changers could tell whether a note was current or not, the paper of broken or suspended banks remaining in circulation long after their value had departed. Through [a national currency] the people will ... gain that deliverance from the previous confusion of their currency which to Europeans appeared a barbarism.

\footnotetext{
${ }^{3}$ For an excellent discusion of Banknote Reporters and Counterfeit Detectors see Dillistin (1947).
} 
The same conclusion has been stated by some more recent writers. For example, Phillip Cagan (1963) asserts:

The nation could not so easily have achieved its rapid industrial and commercial expansion during the second half of the 19th century with the fragmented currency system it had during the first half....

These statements seemingly are based on the presumption that a uniform currency is better than a nonuniform one. ${ }^{4}$ Theoretical support for a presumption in favor of a uniform currency can be found in models like that of Ravikumar and Wallace (2000). In such models, currencies are fiat (intrinsically useless) objects used to overcome transactions frictions. Nonuniformity of currencies is bad, because it limits the potential trades that can occur. An implication is that the replacement of notes issued by state banks by notes issued by national (federally chartered) banks, which for all intents and purposes were a uniform currency, was a welfare improvement. ${ }^{5}$

Notes issued by state banks, however, were not fiat currencies. They gave the bearer the option to exchange them for gold, which was valued in and of itself. As Wallace (2001) has pointed out, if state bank notes are considered to be "payable-to-the-bearer securities [because of this redemption option], then we might be more reluctant to accept the conclusion that they should trade at par," (p 2) and, as a consequence, to question the presumption that a uniform banknote currency would have been a welfare improvement on the actual system. ${ }^{6}$

\footnotetext{
${ }^{4}$ By a uniform currency, I mean that units of distinct currencies with the same numerical designation always trade at par with each other and buy the same quantity of goods at a given location at a given time.

${ }^{5}$ National bank notes came into existence with the passage of the National Currency Act (later called the National Banking Act) in 1863. State banknotes continued to circulate until the passage of a 10 percent tax on them levied in 1866 effectively drove them out of circulation.

${ }^{6}$ Of course, such a finding does not imply that there might not have been other institutional changes with regard to banking and transactions arrangements that would have been welfare improving during this period.
} 
The purpose of this paper is to determine the extent to which the behavior of the prices of banknotes during the antebellum period is consistent with the view that they were securities. It does so by developing some pricing implications of considering banknotes to be securities and then examining the extent to which the data are consistent with view.

Following Gorton (1999), the paper takes the position that if banknotes are considered to be securities, their price should equal their expected net redemption value - the expected rate at which notes can be redeemed for specie less the cost of redeeming notes at the issuing bank. Although the actual pricing equation developed in this paper differs from the BlackScholes banknote pricing equation obtained by Gorton (1999), the testable implications of the analysis are similar.

The proposition that the price of banknotes should equal their expected net redemption value has at least two implications that can be taken to the data. The first is that prices of banknotes should have moved with changes in expected gross redemption rates as, for example, can be presumed to have occurred during periods when banks had suspended specie payments on their notes. The second is that prices of banknotes should have reflected changes in transportation costs since these should have affected the cost of redeeming bank notes.

The paper finds two pieces of evidence consistent with the proposition. First, gross redemption rates matter for the pricing of banknotes. The discounts on banknotes generally are lower when banks are redeeming their notes in specie on demand than when banks have temporarily suspended specie payments. Second, the cost of redeeming notes appears to matter for the pricing of banknotes. The discounts on banknotes are positively correlated with the cost of getting from the location where the banknote price is being quoted to the location of the issuing bank. 
However, the paper also finds evidence that is inconsistent with the proposition. First, the relationship between discounts and redemption costs is not tight. There are several cases in which the discounts on notes of banks in several different locations are the same even though the cost of travel varies greatly. Further, there are several cases in the discounts on the notes of banks in several different locations vary greatly even though the cost of travel to these locations is the same. In addition, changes in the discount on the notes of banks in the same location do not systematically vary with changes in the cost of travel to that location. Second, the paper finds that there are asymmetries in banknote prices in the sense that prices quoted in location $i$ for notes of banks in location $j$ do not generally equal the price quoted in location $j$ for notes of banks in location $i$.

Thus, I conclude that statebank notes were not priced to equal their expected net redemption value, so that the question of how the prices of state banknotes were determined remains an open one. A richer theory is need to explain the prices of banknotes during this period. Based on the empirical evidence presented here, I would argue that such a theory should take into account not only the fact the suspension of specie payments affected the price of banknotes, but also the fact that notes of different banks could have different degrees of acceptability in different transactions. This richer theory is needed before one can answer the question of whether a uniform currency would have been a welfare improvement on the state banknote currency.

The paper proceeds as follows. The next section presents an explicit formulation of the proposition that the price of a banknote should equal its expected net redemption value - the expected rate at which the note can be redeemed for specie less the cost of redeeming the note at the issuing bank. Section two contains a description of the data on bank note 
prices used in this study. Section three shows that the gross redemption rates affect prices by comparing banknote prices in periods when specie payments are suspended with periods when banks are redeeming notes for specie. Section four examines the relationship between note prices and redemption costs. Section five demonstrates that there existed asymmetries in banknote prices quotations depending on the location of the quote. Section six concludes.

\section{Banknotes as securities}

The proposition that banknotes were priced to equal their expected net redemption value is obtained as follows. Consider what a local (location $j$ ) note broker earns by exchanging notes of an arbitrary local bank for the notes of bank $i$. (It is convenient to think of bank $i$ as located elsewhere, but it could be another local bank.) After the exchange, the broker ships the notes to the location of bank $i$ and receives $q_{t^{\prime}}(i)$ dollars of gold for each dollar of bank $i$ notes presented for redemption. The time subscript on this redemption rate is $t^{\prime}$ not $t$ to account for the fact that what matters is the redemption rate when the note is presented in the future, not the redemption rate when the broker buys the note. If bank $i$ is redeeming its notes in gold (the bank is not suspended) at $t^{\prime}$, then $q_{t^{\prime}}(i)=1$. If it is suspended, then $q_{t^{\prime}}(i) \leq 1$. The broker then brings the gold back to the current location and exchanges it for local bank notes at the rate of $1 / q_{t^{\prime \prime}}(j)$ local bank notes per dollar of gold. The time subscript is $t^{\prime \prime}$ to account for the fact that what matters is the local redemption rate when the broker gets the gold back to the home location. The broker must also pay the cost, $\delta_{t}(i, j)$ of taking

the notes to bank $i$ and returning with the gold. I assume that this cost is proportional to the size of the transaction and is known at $t$. Thus, if $E_{t}$ expectation operator conditional 
on information at $t$, the expected net redemption rate for notes of bank $i$ is

$$
E_{t}\left[\frac{q_{t^{\prime}}(i)}{q_{t^{\prime \prime}}(j)}\right]\left[1-\delta_{t}(i, j)\right]=p_{t}(i, j)
$$

where $p_{t}(i, j)$ denotes the price of a dollar of the notes of bank $i$ in terms of the notes of banks in $j$ at time $t$. The discount on the notes of bank $i$ is $d_{t}(i, j)=1-p_{t}(i, j)$.

\section{Data}

The data for this study are discounts or premiums on the notes of individual banks as quoted in four locations - Philadelphia, New York, Cincinnati, and Cleveland. All data used in this study are available at my website: http://minneapolisfed.org/research/economists/ wewproj.html.

There are bimonthly data for New York for the period July 1817 through December 1849 and monthly data for January 1850 through November 1852 from Shipping $\&$ commercial list (and New-York price current). This source also has observations for October and November 1853 and for July, August, and December 1856. Additionally, there are data for November 1853, August 1854, December 1855, all months of 1857 except March, and June 1858 from Thompson's Bank Note and Commercial Reporter (Thompson's). ${ }^{7}$

The data for Philadelphia is monthly for the period August 1830 through January 1831 and August 1832 through December 1858. The data through January 1839 is from Bicknell's Reporter, Counterfeit Detector, and General Prices Current (Bicknell's). The later data are all from Van Court's Counterfeit Detector and Bank Note List (Van Court's). ${ }^{8}$

\footnotetext{
${ }^{7}$ Like Bicknell's and Van Court's, Thompson's had several titles. See Dillistin for a discussion (pp 83 93).

${ }^{8}$ Actually, these publications had several different titles during these periods. These different titles are discussed in Dillistin (1949). See p 126 for a discussion of Bicknell's and pp 132-134 for a discussion of Van Court's.
} 
For Cincinnati, I have observations for February 1841 and for July 1845 through June 1847 from Goodman's Western Counterfeit Detector and Bank Note Table, February 1850 from Lord's Bradley 83 Co.'s Cincinnati Counterfeit Detector and Bank Note Reporter, and July 1854 from Lord's Detector and Bank Note Reporter.

I have three observations for Cleveland. They are January, June, and September 1856 from the Cleveland Bank Note Reporter published by Pierce \&Co., bankers.

Discounts and premiums are quoted for banks throughout the country in terms of notes of banks in the particular city where the bank note reporter is published. They are not quotes for exchanges of bank notes for specie. When banks are redeeming their notes for specie, this difference is not important. However, as shown below, it makes a difference when banks have suspended specie payment on their notes.

The focus in the paper is the prices of notes of banks that are actually in business. Consequently, quotes for the notes of banks that are "closed," "winding up," or "broken" are not taken into account. After these the quotes for such banks are eliminated, I have over 200,000 individual banknote price observations covering over 2000 banks.

\section{Bank note discounts during bank suspensions}

The expectation term in (1) is the expected exchange rate of gold for notes of bank $i$ relative to the exchange rate of gold for local bank notes. When bank $i$ and local banks are expected to be redeeming their notes from $t$ through $t^{\prime \prime}$, this term is equal to one since notes in both locations are exchanging for gold at par. Then, from (1) and the definition of the discount on a note

$$
d_{t}(i, j)=1-\delta_{t}(i, j)=\tilde{d}_{t}(i, j) .
$$


The discount on the notes of bank $i$ should be equal to the cost of redeeming its notes.

However, when bank $i$ is expected to be suspended at $t^{\prime}$, but local banks are expected to continue to redeem their notes through $t^{\prime \prime} ; E_{t}\left(q_{t^{\prime}}^{i} / q_{t^{\prime \prime}}^{j}\right) \leq 1$, because notes of bank $i$ maybe be going at a discount against specie where bank $i$ is located. Then, from (2)

$$
d_{t}(i, j) \geq \tilde{d}_{t}(i, j)
$$

Thus, if banknotes were priced equal to their expected net redemption value, the discount on the notes of bank $i$ should be at least as large when it is suspended than when it is not during times when local banks are redeeming their notes.

Using the same logic, $d_{t}(i, j) \leq \tilde{d}_{t}(i, j)$ for the case in which bank $i$ is expected to redeem its notes at $t^{\prime}$, but local banks are expected to be suspended through $t^{\prime \prime}$. Thus, if banknotes are priced equal to their expected net redemption value, the discount on the notes of bank $i$ during times when it is redeeming its notes should be no larger when local banks are suspended than when they are not.

During the period from May 1837 until the end of 1842 there are episodes when some banks were suspended while other banks were not that can be used to test these predictions. I am able to determine the dates of specie payment suspensions and resumptions for banks in the cities of New York, Philadelphia, Baltimore, Charleston, Cincinnati, and New Orleans, banks in the states of North Carolina and Kentucky, and for the Bank of Virginia during this period. A summary of these dates is given in Table 1.

The table shows that there are two episodes when banks in New York are redeeming their notes in specie, but banks in the other locations in the table are not: one from May 1838 to August of that year (or December in the case of New Orleans) and a second beginning in 
October 1839 and lasting until July 1840 in the case of Charleston and until various times in 1842 for banks in the other locations.

The discounts quoted in New York on the notes of banks in the other locations listed in Table 1 are shown in Figures 1 through 8 for the period 1835 through 1844. (Throughout this discussion, I will use the term foreign banks to designate the subset of banks in locations other than that where the discount is being quoted.) Periods when foreign banks and New York banks are redeeming are shown in thick dark gray; periods when foreign banks are suspended and New York banks are redeeming are shown in black; and periods when foreign banks and New York banks are suspended are shown in thin light gray. In dating the discounts, I assume that the date of the discount is date of the publication in which it appears.

Testing whether the discounts in these figures are consistent with the banknotes-assecurities view requires an estimate of $\tilde{d}_{t}(i, j)$ for banks in each location. For this I use the average discount on the notes of banks in a particular location for the period between 1835 and 1840 when both the banks in that location and New York banks are redeeming their notes. Obviously, this choice is somewhat arbitrary. My justification is that it covers a long enough period to insure that the results are not sensitive to a few outliers, but that the period is short enough that changes in the cost of redeeming notes should not have changed very much. It is also the case that extending the time period in either direction only makes the evidence more consistent with the view that prices were determined by net redemption value. My estimate of $\tilde{d}_{t}(i, j)$ for banks in each location is shown by the black dashed line in each figure. For the data to be consistent with the prediction of the banknotes-as-securities view, the discounts in black would always have to lie above this line. 
The evidence for all locations except New Orleans is consistent with banknotes priced equal to expected net redemption value in the sense that the solid black line always lies above the black dashed line. The strongest support comes from the discounts on the notes of Philadelphia banks. Not only are the discounts on the notes of Philadelphia banks in Philadelphia-banks-suspended-New York-banks-redeeming case always above the black dashed line, but they are also always higher than at any time when banks in both places are redeeming. This can be seen in Figure 1.

For banks in the other locations, excluding New Orleans, there some times when the discounts on their notes in the foreign-banks-suspended-New-York-banks-redeeming case are smaller than some of the discounts when banks in both places are redeeming. However, these periods are few and short-lived. Further, the large discounts when banks in both places are redeeming mostly occur immediately before times of bank suspensions, and it may not be reasonable to assume $E_{t}\left[q_{t^{\prime}}(i) / q_{t^{\prime \prime}}(j)\right]=1$ at such times. Hence, I conclude that the evidence for banks in these locations also is consistent with banknotes priced equal to expected net redemption value .

The evidence for New Orleans is less consistent with banknotes priced equal to expected net redemption value. There are two periods when New Orleans banks are suspended and New York banks are redeeming, yet the discounts on the notes of New Orleans banks fall below the black dashed line. These occur from October through December 1838 and from October 1840 to early February 1841. Nonetheless, for New Orleans banks it is the case that the vast majority of discounts when New Orleans banks are suspended but New York banks are not are larger than when banks in both locations are redeeming. 
My conclusion is that, taken as a whole, the evidence from the discounts as quoted in New York is consistent with what prices would be if banknotes were priced to equal their expected net redemption value.

There is an interesting regularity that also appears in these figures. The discounts on the notes of local banks always increase when banks in New York suspend payments regardless of whether or not local banks suspend at the same time. The only case in which this does not occur is for the Bank of Virginia.

As can be seen from Table 1, there are other episodes when banks in one location are redeeming while banks in some other locations are not that can be used to test the predictions of the banknotes-as-securities view. Specifically, during 1842 there is a time when banks in Philadelphia have resumed redeeming their notes, but the Bank of Virginia, the Bank of Louisiana, and banks in Kentucky and North Carolina continue to be suspended.

The discounts quoted in Philadelphia on the notes of the Bank of Virginia and the Bank of Louisiana are shown in Figures 9 and 10 for the period 1839 through $1844 .^{9}$ I use the same conventions for the lines in these figures as in Figures 1 through 8 . The results are very similar to those for the discounts as quoted in New York. Specifically, the discounts in black (foreign bank suspended) always lie above the black dashed line (estimate of $\tilde{d}_{t}(i, j)$ ). Further, for the Bank of Virginia, the discounts on their notes are always at least as large in the foreign-bank-suspended-Philadelphia-banks-redeeming case as when banks in both places are redeeming. Thus, I conclude that this evidence on discount quotes from Philadelphia is also consistent with banknotes priced equal to expected net redemption value.

\footnotetext{
${ }^{9}$ The discount data are for the Bank of Louisiana, not for all New Orleans banks since the Philadelphia discount quotations for New Orleans banks differ by bank. This was not true for New York discount quotations. There the discounts were listed simply for all New Orleans banks. [check wording this source]
} 
The evidence presented above is all cases when foreign banks are suspended and local banks are redeeming versus discounts when both are redeeming. The fact that I have quotations from Philadelphia permits tests for the opposite case, because there are periods when Philadelphia banks are suspended but banks in some other locations are not. As noted above, if banknotes are priced equal to expected net redemption value, the discounts on notes of redeeming foreign banks should be no larger during these times than during times when Philadelphia banks are also redeeming their notes.

There are three episodes that I consider. The first two are the times when Philadelphia banks were suspended but New York banks were not. These are the same episodes considered in the discussion of discount quotes from New York, but I now consider it from the point of view of discounts quoted in Philadelphia. The discounts on the notes of New York banks as quoted in Philadelphia for this period is shown in Figure 11, and these are consistent with the prediction of the theory since they are never larger when during periods when Philadelphia banks are suspended than when they are redeeming. In fact, the figure shows that during the second suspension by Philadelphia banks, notes of New York banks were commanding a substantial premium in Philadelphia.

The third episode is that beginning in July 1840 when Charleston banks resumed specie payments, but Philadelphia banks did not until March 1842. The discounts the notes of Charleston banks as quoted in Philadelphia for 1839 - 1844 are shown in Figure 12. The evidence here is less favorable to the banknotes-as-securities view than that in Figure 11, but only slightly less so. Until January 1844, the discounts quoted in Philadelphia on the notes of Charleston banks are never less than 1 percent when Philadelphia banks and Charleston banks are both redeeming their notes in specie. However, when Philadelphia banks are suspended 
and Charleston banks are redeeming, the discount is 1 percent or less except for March and April 1841.

Taken altogether, I conclude that the evidence from the periods when banks in one location are redeeming whereas banks in another location are not is consistent with the banknotes-as-securities view of how banknotes were priced during the antebellum period.

\section{Bank note discounts and redemption costs}

If banknotes are priced to equal to expected net redemption value, then (1) predicts that the discount on a bank's notes should be positively related to the cost of redeeming its notes, $\delta_{t}(i, j)$. I now test this prediction in two ways. The first is by considering a cross section of banks with different redemption costs at a point in time when all banks can reasonably be expected to be redeeming their notes The second is by examining whether known changes in redemption costs over time affect the discount on a bank's notes. The evidence I examine is always from periods during which all banks could reasonably be expected to be redeeming their notes. In other words, I assume that $E_{t}\left(q_{t^{\prime}}^{i} / q_{t^{\prime \prime}}^{j}\right)=1$ for all $i, j$ during the time periods used to test this prediction. By limiting the examination to such period, there are no issues about expected differences in gross redemption values affecting the discounts of different banks.

\section{A. Cross sectional evidence}

I first consider the case in which the notes of bank $k$ are more costly to redeem in location $j$ than are the notes of bank $i ; \delta_{t}(i, j)<\delta_{t}(k, j)$. When this is the case, the banknotesas-securities view predicts that $d_{t}(i, j)<d_{t}(k, j)$, the discount of the notes of bank $i$ should be lower than the discount on the notes of bank $k$. It is this prediction that I test in this 
section. I do so by considering cross sections of banks at several times.

To select locations of banks with which to test this prediction, I examined Disturnell's Guide through the Middle, Northern, and Eastern States for 1847 and Disturnell's Railway and Steamship Guide for 1854 and 1855 (I will refer to all three as Disturnell's) to find cities for which I could obtain information on the cost or distance of traveling to them from New York and from Philadelphia.

Then, I eliminated from this list those cities in which banks had some type of special note redemption arrangements that would have affected the discounts on their notes. Specifically, I eliminated all cities in New England expect Boston, because of the presence of the Suffolk Banking System, a note clearing arrangement that virtually all New England banks participated in during this period. While this System was in place, the notes of all New England banks went at par in that region, which meant that all banknotes in that region were quoted at the same rate of discount. I also eliminated all cities in the state of New York except Albany. After 184x, every New York bank was required to have an agent bank in either New York or Albany that would redeem its notes at no greater than a xx percent discount. I also eliminated virtually all cities in New Jersey because they had par redemption arrangements with banks in either New York or Philadelphia, and I eliminated all cities in Delaware and several cities near Philadelphia because they had par redemption arrangements with banks in that city. Finally, I eliminated all cities in Ohio except Cincinnati and Cleveland because xxx. In the end, I was left with a sample of 32 cities.

There is travel cost information in Disturnell's for travel from New York or Philadelphia to many of these cities. This information is the price of a ticket to get from either of these locations (a one way fare) to a city in the sample. By 1854, this is the price of a railroad 
ticket in most case. However, there are cases, including that of getting from Philadelphia to New York, in which a steamboat or ferry trip was also involved. Further, getting to Mobile and New Orleans involved taking a stagecoach at least part of the way. Cost information by city is given in the Appendix.

Discounts quoted in New York are plotted against cost in Figures 13 and 14 for 1847 and 1854, respectively. Discounts quoted in Philadelphia in Figures 15 and 16 for the same years. ${ }^{10}$ As the figures show, in all four cases discounts increase with redemption costs consistent with banknotes being priced to equal expected net redemption value. However, the figures reveal several cases in which there are large differences in costs with little or no difference in discounts. In 1847 the cost of getting from New York to Richmond is $\$ 14$, the cost of getting to Mobile is $\$ 64$, and the cost of getting to New Orleans is $\$ 69$. Yet the notes of banks in all three locations had an average quoted discount during that year of approximately 1.1 percent. For Philadelphia for the same year, the cost of getting to Charleston was $\$ 25$ and the cost of getting to New Orleans was $\$ 66$. Yet, the notes of banks in both locations had the same average quoted discount (1.06 percent) during that year.

The figures for 1854 show even more extreme cases in which there are large differences in costs with little or no difference in discounts. In 1854 it cost $\$ 11$ to get from New York to Pittsburgh, Richmond, Cumberland, and Cleveland. Yet the average annual quoted dis-

\footnotetext{
${ }^{10}$ Also plotted in the figures in the regression line for the equation$$
d_{t}^{i j}= \begin{cases}\alpha+\beta \ln \left(\delta_{t}^{i j}\right) & \text { if } \alpha+\beta \ln \left(\delta_{t}^{i j}\right) \geq 0 \\ 0 & \text { otherwise }\end{cases}
$$

for $j=$ New York or Phildelphia. The semi-log form was chosen because it fit the data better than any equation in the class $\left(\delta_{t}^{i j}\right)^{\gamma-1} /(\gamma-1)$. Consistent with the banknotes as securities vies, the estimates of $\beta$ are positively and statistically significant in all four figures.
} 
counts on the notes of banks in these locations ranged from 0.75 percent (Cumberland and Pittsburgh) to 2 percent (Cleveland). It cost $\$ 46.42$ to get from New York to Mobile and $\$ 51.42$ to get to New Orleans. Yet the average annual discount on the notes of banks in these locations was 2 percent, the same as Cleveland. Also, the average annual discount on the notes of banks in Savannah was 1.25, the same as Richmond. Yet, it cost slight more that $\$ 29$ dollars to get to there from New York. The same types of differences also appear in the discounts quoted in Philadelphia.

Unfortunately, I have only been able to find cost of travel data for 1847 and 1854, and it would be nice to see how discounts and redemption costs were related in other years. Since distance and travel cost were highly correlated in 1847 and 1854, distance may be a good proxy for travel costs during this period. Thus, I examined the relationship between bank note discounts and distance for 1836 for both New York and Philadelphia and for 1827 for New York, since discount quotes were not available in Philadelphia at the time. The reason for the choice of these years was to have observations at roughly 10 year intervals, so that I have one entry for each decade beginning with 1827. However, I chose 1836 instead of 1837 to avoid the panic beginning in May of that year discussed above.

The results are shown in Figures 17 and 18 for 1836 and in Figure 19 for 1827. The results in these figures are consistent with those for the later years. Discounts on notes generally increase with the distance of the issuing bank from the location in which the discount is being quoted. However, there are also cases in which there are large differences in discounts without there being large differences in distance. The exception here is the result for discounts quoted in Philadelphia in 1836. Here the figure shows that there are no large outliers. The relationship between discounts and distance is linear and very tight. 


\section{B. Changes in redemption costs}

I now consider the case in which the cost of redeeming the notes of bank $i$ is smaller at time $t_{2}$ than at $t_{1}$; that is $\delta_{t_{1}}(i, j)>\delta_{t_{2}}(i, j)$. Then (1) predicts that $d_{t_{2}}(i, j)<d_{t_{1}}(i, j)$, the discount of the notes of bank $i$ should be lower at $t_{2}$ than at $t_{1}$. It is this prediction that I test in this section.

An examination of Appendix Table 1, shows that there are 17 locations for which it is possible to compare the cost of one way travel between those locations New York between 1847 and 1854. The cost of travel remained the same for 9 locations and fell for the other 8. For Philadelphia, the comparison is possible for 16 locations; travel cost fell in 8 and remained the same in $8 .{ }^{11}$

The movement of discounts on the notes of banks in these locations as quoted in New York and Philadelphia between 1847 and 1854 sorted by change in travel costs in reported in Table 2. The cells shaded gray are those that are consistent with banknotes being priced equal to their expected net redemption value. The results are not favorable to this proposition, because the changes in discounts are essentially independent of the change in travel cost. In Philadelphia, regardless of whether the cost of traveling to a location stayed the same or went down or stayed the same, the discount on banknotes from that location were about as likely to rise as to fall. In New York, when the cost of traveling to a location fell, again the discount on banknotes such a location were as likely to fall as to rise. Only in the case when the cost

\footnotetext{
${ }^{11}$ An examination of Appendix Table 1 would seem to indicate that costs fell for more 9 locations in both cities. However, the cost of getting from Philadelphia to Baltimore in 1847 is either $\$ 4$ or $\$ 3$ depending upon the method of transportation. I chose $\$ 4$ because it took less time. The cost was $\$ 3$ in 1854 . Since this cost factored into the costs for several other cities, I regarded all of them as having the same cost in both years. Assuming that the travel cost to these cities fell from 1847 to 1854 instead of being unchanged does not change the overal results.
} 
of traveling to a location remained the same was the discount on notes more likely to remain unchanged or to fall than to rise.

\section{Price asymmetries}

It seems reasonable to assume that during the period under consideration the cost of going between two locations was the same regardless of which direction one is going. If so, the cost of redeeming bank notes was symmetric across locations; that is, $\delta_{t}(i, j)=\delta_{t}(j, i)$.

Now consider the time periods when it reasonably could be assumed that banks in both locations were expected to be redeeming their notes. During such periods, $E_{t}\left[q_{t^{\prime}}(j) / q_{t^{\prime \prime}}(i)\right]=$ $E_{t}\left[q_{t^{\prime}}(i) / q_{t^{\prime \prime}}(j)\right]=1$. Then if banknotes are priced to equal their expected net redemption value, from $(1), d_{t}(i, j)=d_{t}(j, i)$. The discount on banknotes should be symmetric; the discount on the notes of bank $i$ in location $j$ should be the same as the discount on the notes of bank $j$ in location $i$.

Since I have banknote discount quotes from several locations, I can test this prediction. Specifically, given my data, I am able to examine three possible cases to see if banknote discounts are symmetric. Contrary to the prediction, I find persistent, long-lasting asymmetries in each of the three cases.

First, I compared the discount on the notes of Philadelphia banks in New York with the discount on the notes of New York banks in Philadelphia for the period 1845 through 1856, a period during which banks in both locations were redeeming and for which I had good data. The notes of Philadelphia banks were uniformly at a $\frac{1}{4}$ percent discount in New York. In contrast, the notes of New York banks were never at a discount greater than 1/8 percent in Philadelphia and there were times when they were quoted at par. 
Second, I compared the discount on the notes of Cincinnati banks as quoted in Philadelphia and as quoted in New York with the discount on the notes of New York and Philadelphia banks as quoted in Cincinnati. I did this for each point in time that I had an observation on quotes in Cincinnati. The notes of Cincinnati banks were always at discounts of 1 percent or greater in New York and Philadelphia. However, the notes of New York and Philadelphia banks were always quoted at par in Cincinnati.

Lastly, I did the same comparison for the discount on the notes of Cleveland banks as quoted in New York and as quoted in Philadelphia with the discounts on the notes of New York and Philadelphia banks as quoted in Cleveland. I only did this for 1856 since that is the only time when I have discount quotes for Cleveland. I find that the notes of Cleveland banks were at a 1 percent discount in both New York and Philadelphia during that year. However, as was the case for the quotes from Cincinnati, New York and Philadelphia banknotes were quoted at par in Cleveland.

\section{Conclusion}

Prior to 1860 there were a large number of currencies circulating in the United States. These were the notes issued by the numerous state chartered banks that existed during this period. In general, these notes did not circulated at par against each other, and the exchange rates among these various currencies varied over time.

This paper examines the determinants of the prices of the notes of the state-chartered banks that were in existence during this period in terms of the notes of banks in New York, Philadelphia, Cincinnati, and Cleveland. Specifically, the paper examines whether banknotes were priced to equal their expected net redemption value. 
There are three major findings, one of which is consistent with this view about how banknotes were priced and two which are not. The finding that is consistent with this view is the expected gross redemption values affected banknote prices. The price of the notes of a bank was higher when it was redeeming its notes for specie on demand than when it was not.

The first finding that is not consistent with banknotes being priced equal to net expected redemption value is the although the discounts on banknotes are positively correlated with the cost of redeeming notes, this relationship is not tight. There several instances where the discounts on banks in different locations are the same even though the cost of redeeming the notes is markedly different. There are also several instances where the cost of redeeming notes of banks in different locations are roughly the same, but the discounts on their notes is markedly different. The second finding that is not consistent with this view is that the discounts on banknotes are not symmetric. The location in which the discount is being quoted matters.

My conclusion from the empirical evidence is that the hypothesis that banknotes were priced to equal their net expected redemption value is not correct. Instead, to understand how bank note prices were determined during this period, we need a richer theory. 


\section{References}

Cagan, Phillip. 1963. The first fifty years of the National Banking System - An historical appraisal. in Carson, Dean, ed. Banking and Monetary Studies. Homewood, IL, Richard D. Irwin, Inc.

Dillistin, William H. 1949. Bank Note Reporters and Counterfeit Detectors 1826 - 1866. New York, The American Numismatic Society.

Gorton, Gary. 1999. Pricing free bank notes. Journal of Monetary Economics. 44, 33-64.

Ravikumar, B. and Wallace, Neil. 2001. A benefit of uniform currency. Manuscript, The Pennsylvania State University. 
Figure 1: Discounts on notes of Philadelphia banks as quoted in New York, 1835 - 1844

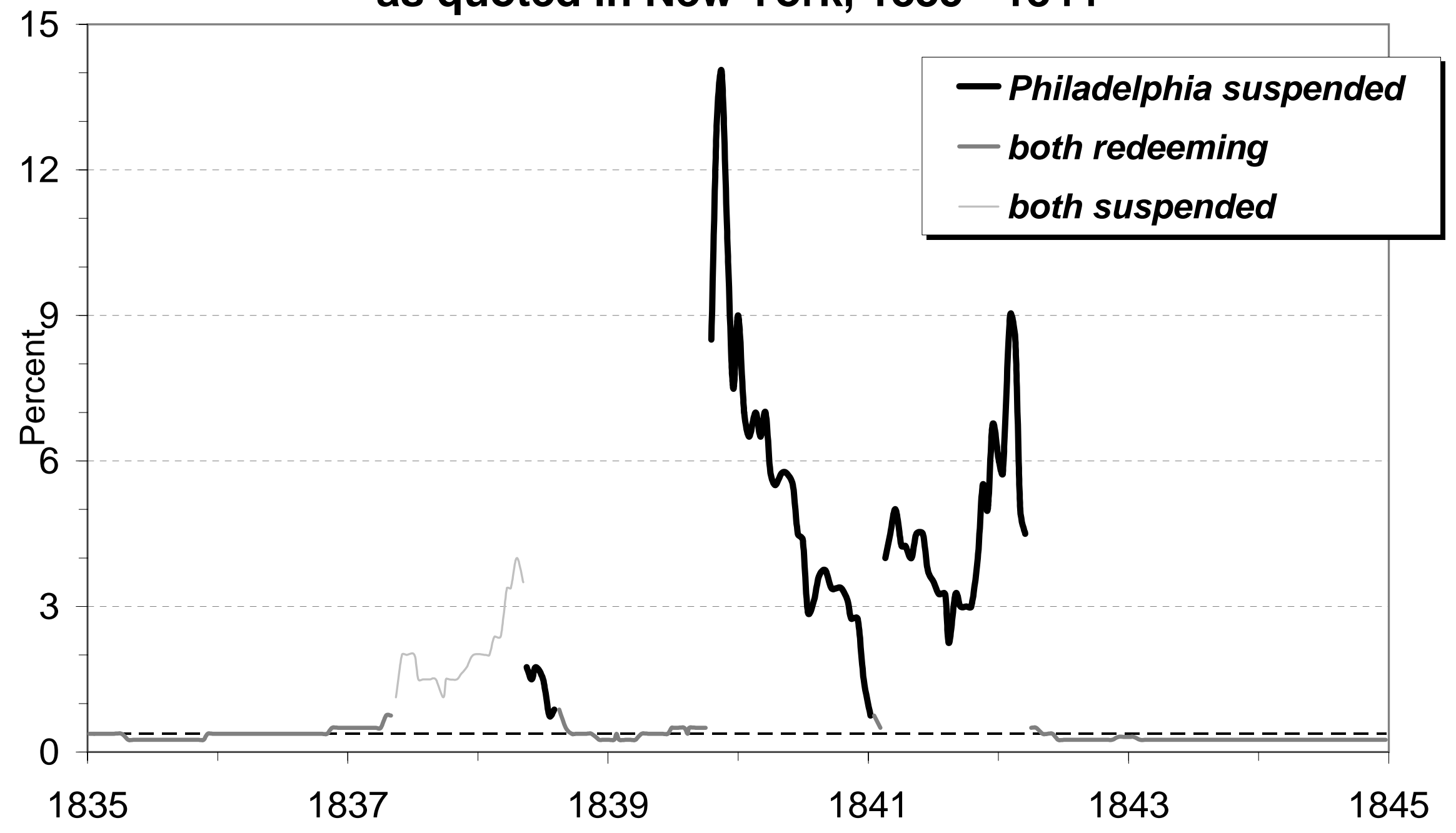


Figure 2: Discounts on notes of Baltimore banks as quoted in New York, 1835 - 1844

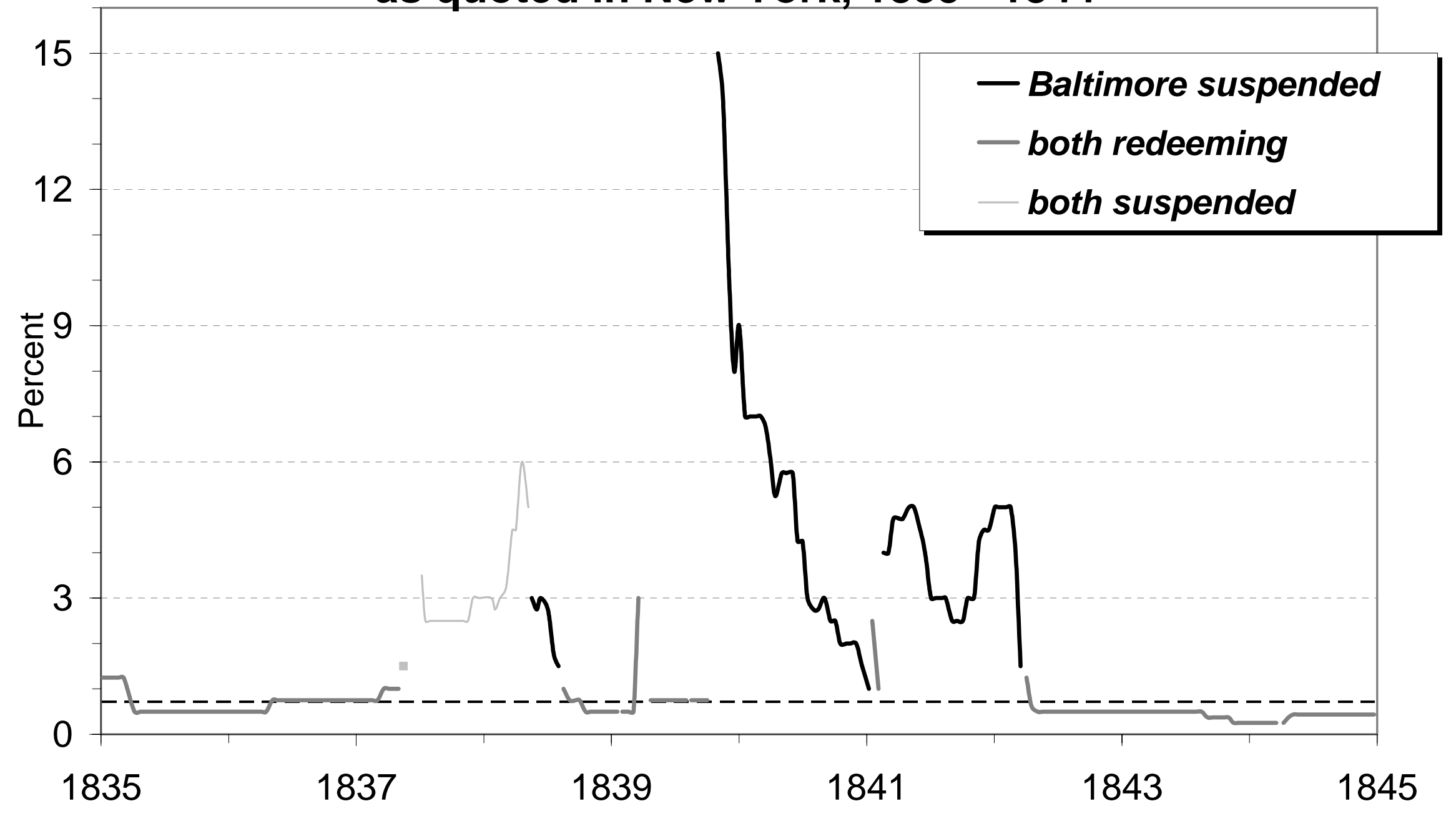


Figure 3: Discounts on notes of Charleston SC banks as quoted in New York, 1835 - 1844

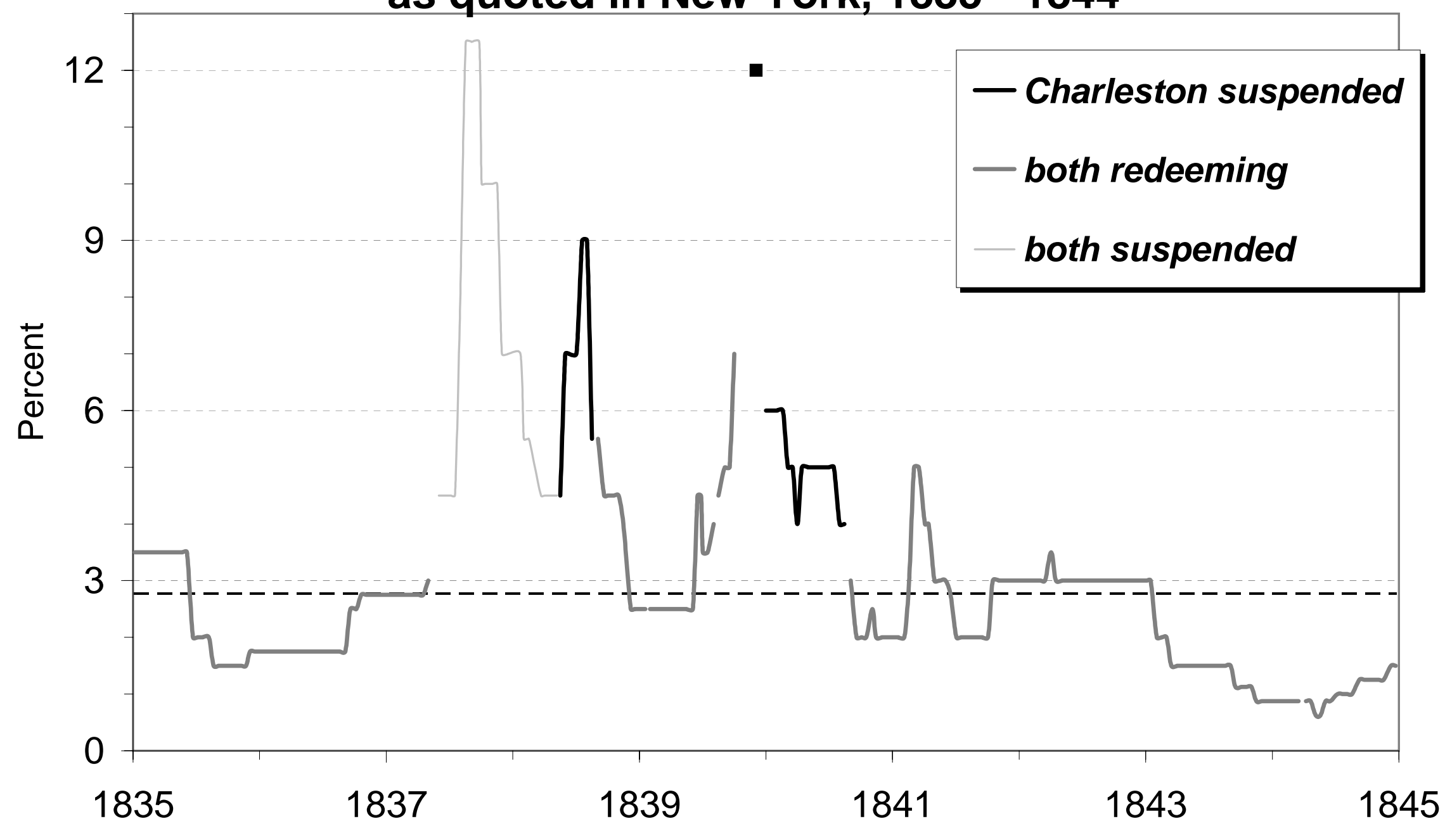


Figure 4: Discounts on notes of Cincinnati banks

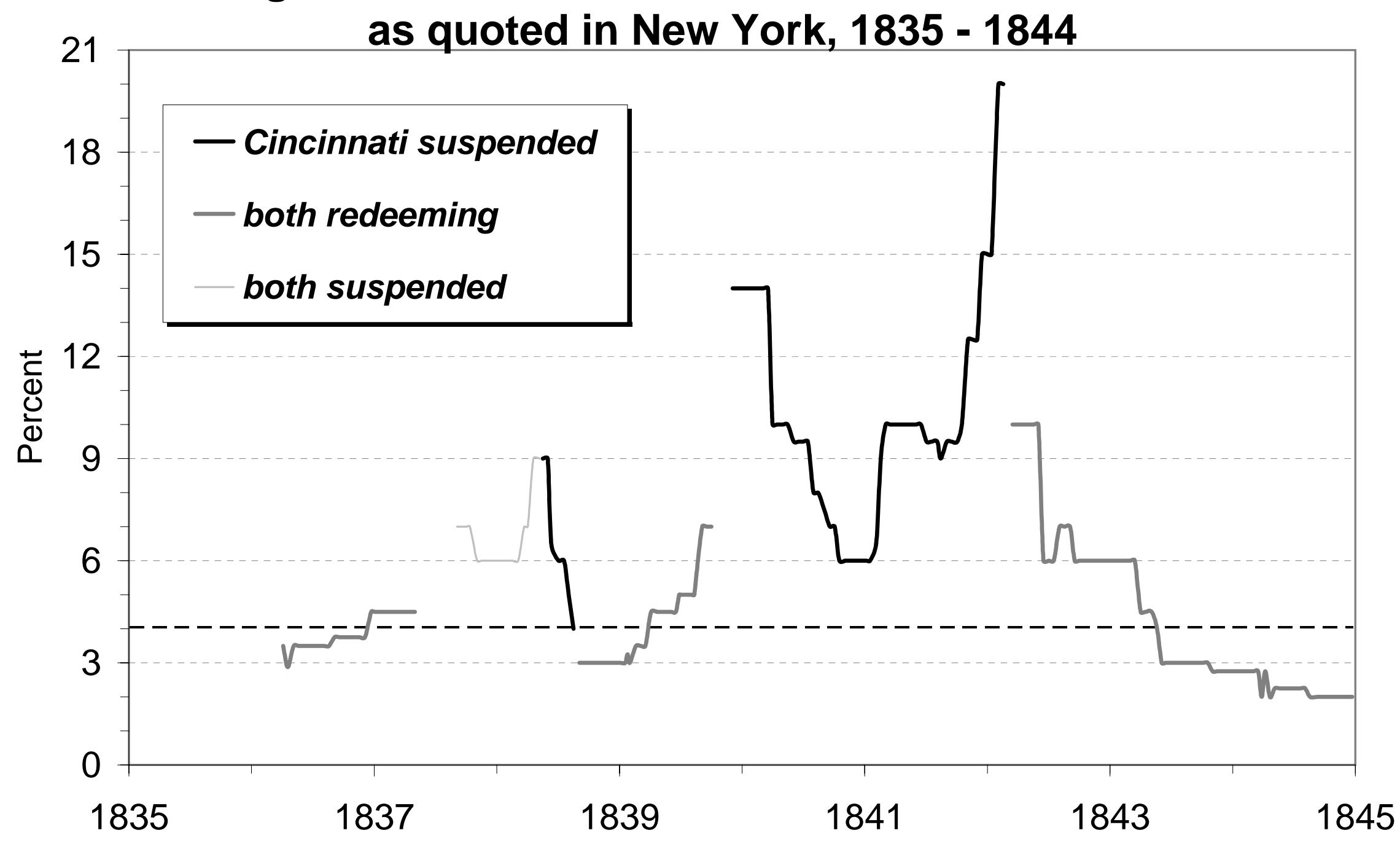


Figure 5: Discounts on notes of North Carolina banks as quoted in New York, 1835 - 1844

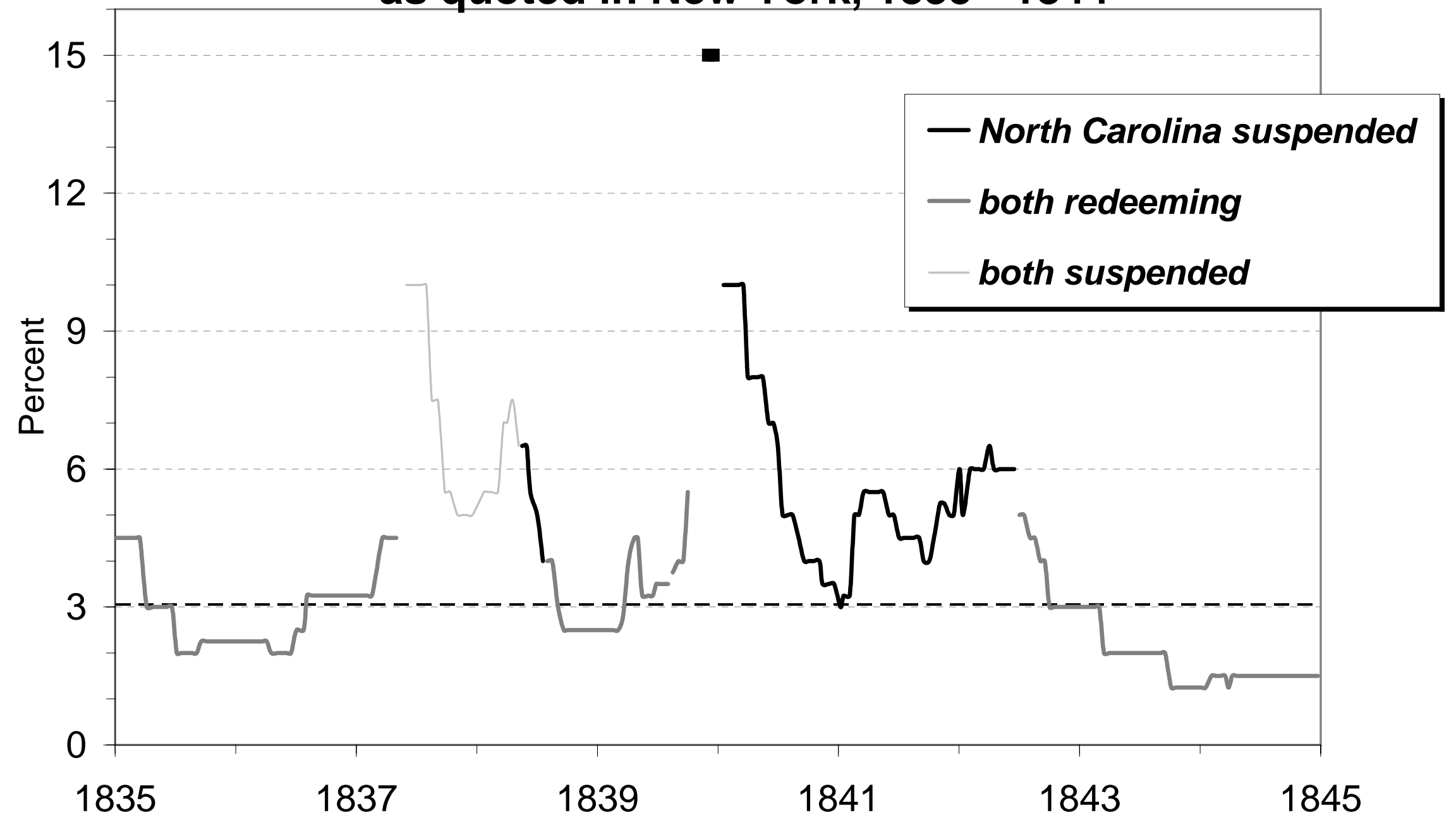


Figure 6: Discounts on notes of Kentucky banks

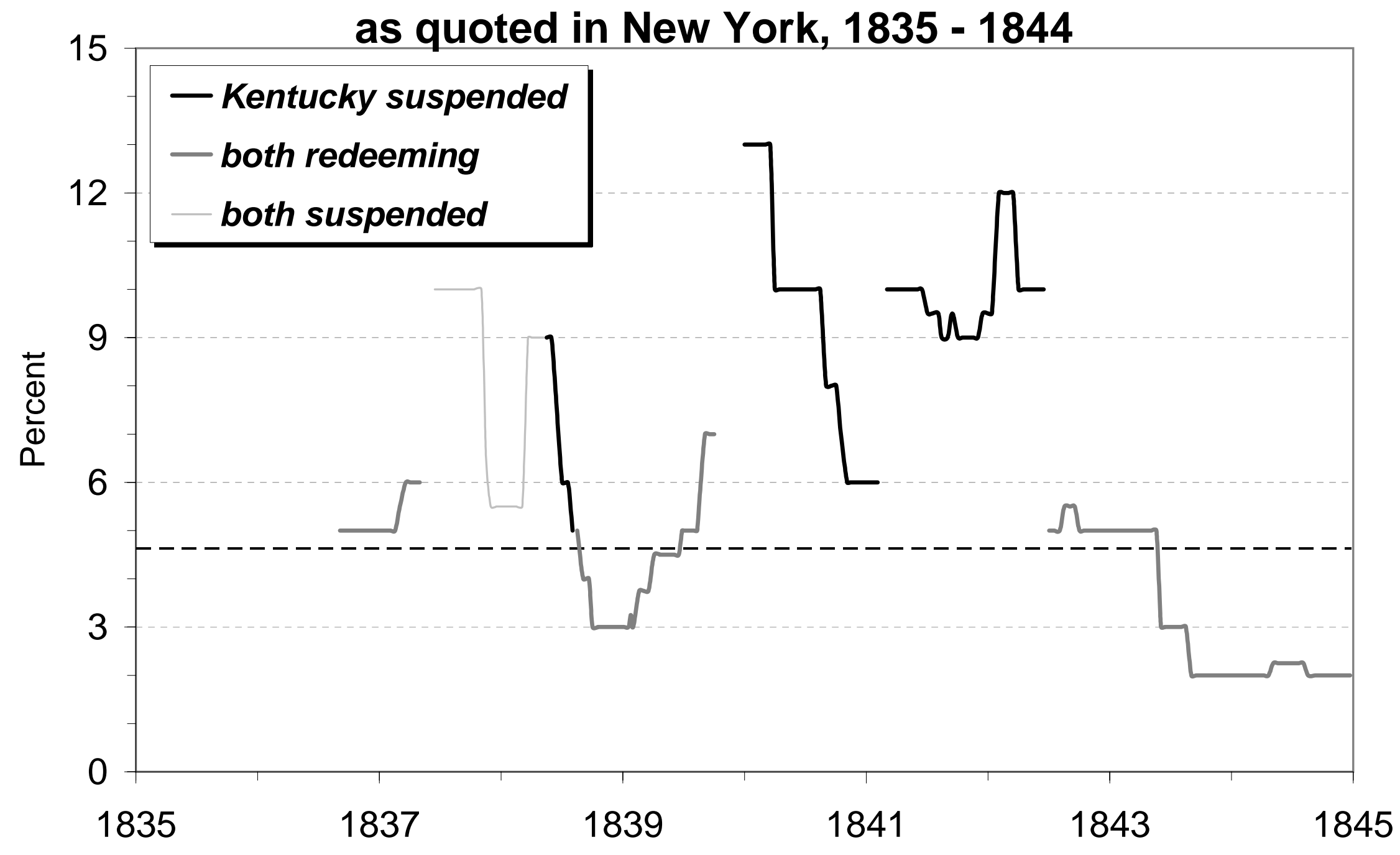


Figure 7: Discounts on notes of the Bank of Virginia as quoted in New York, 1835 - 1844

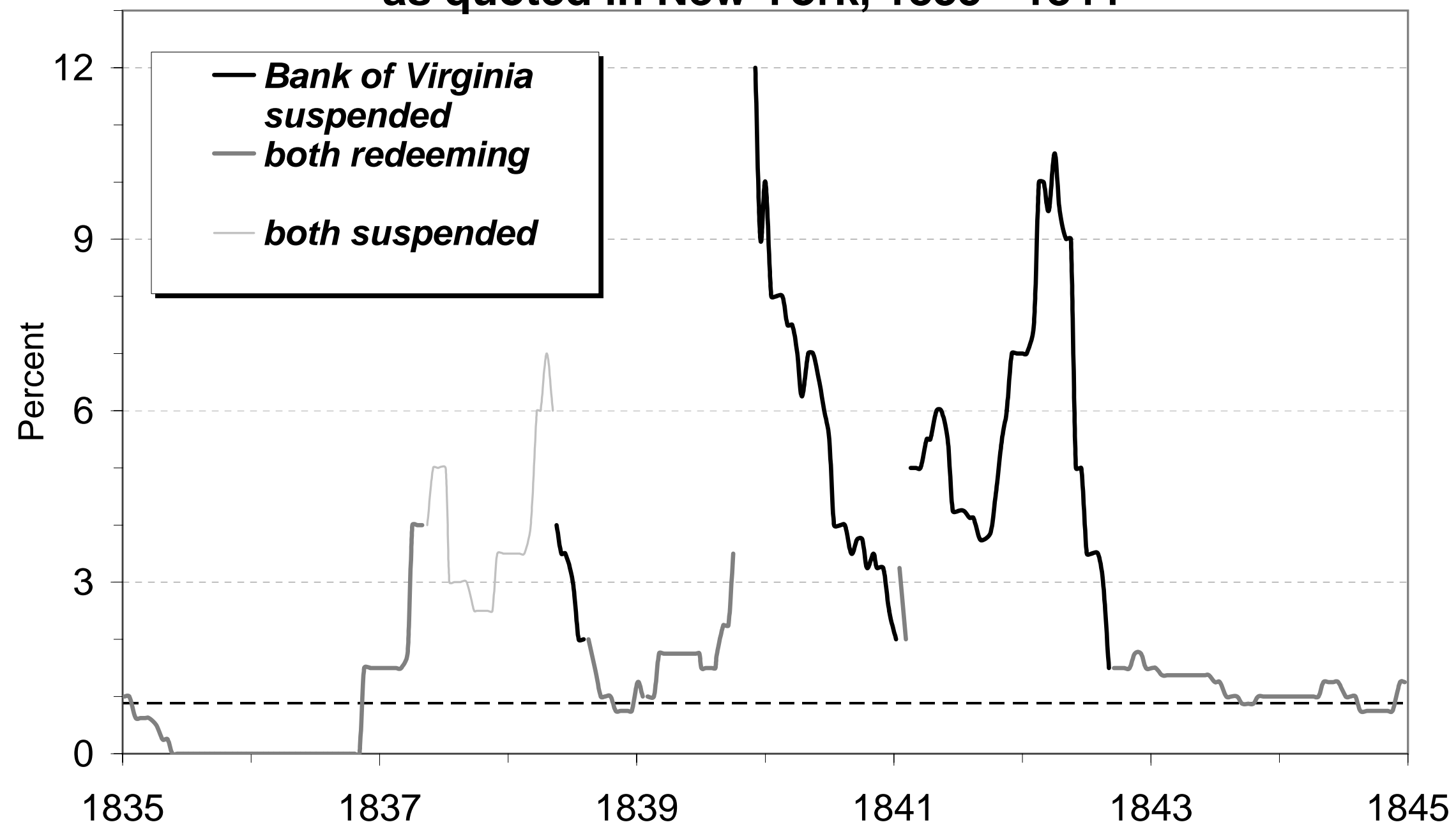


Figure 8: Discounts on notes of New Orleans banks

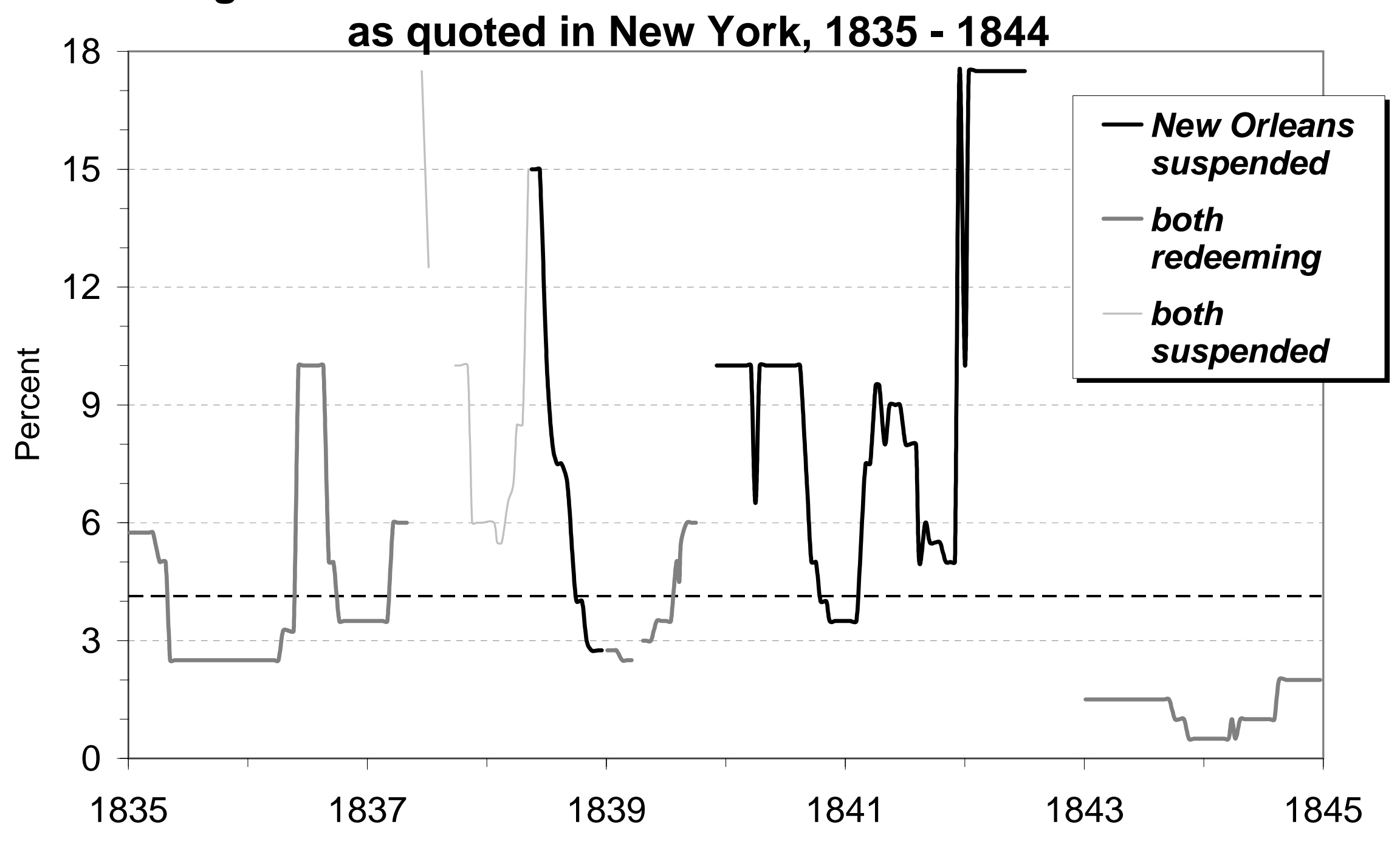


Figure 9: Discounts on notes of the Bank of Virginia as quoted in Philadelphia, 1839 - 44

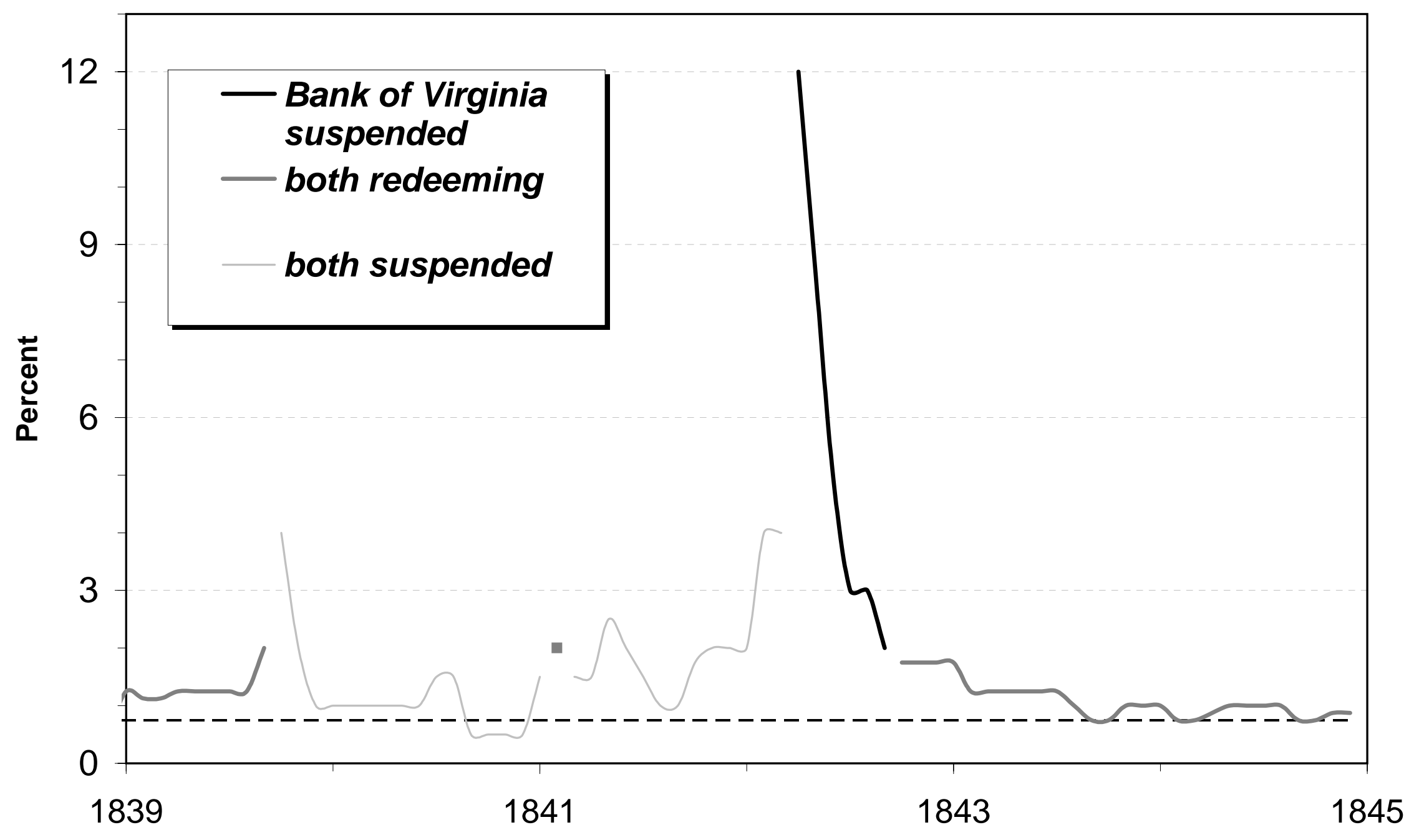


Figure 10: Discounts on notes of the Bank of Louisiana as quoted in Philadelphia, 1835 - 44

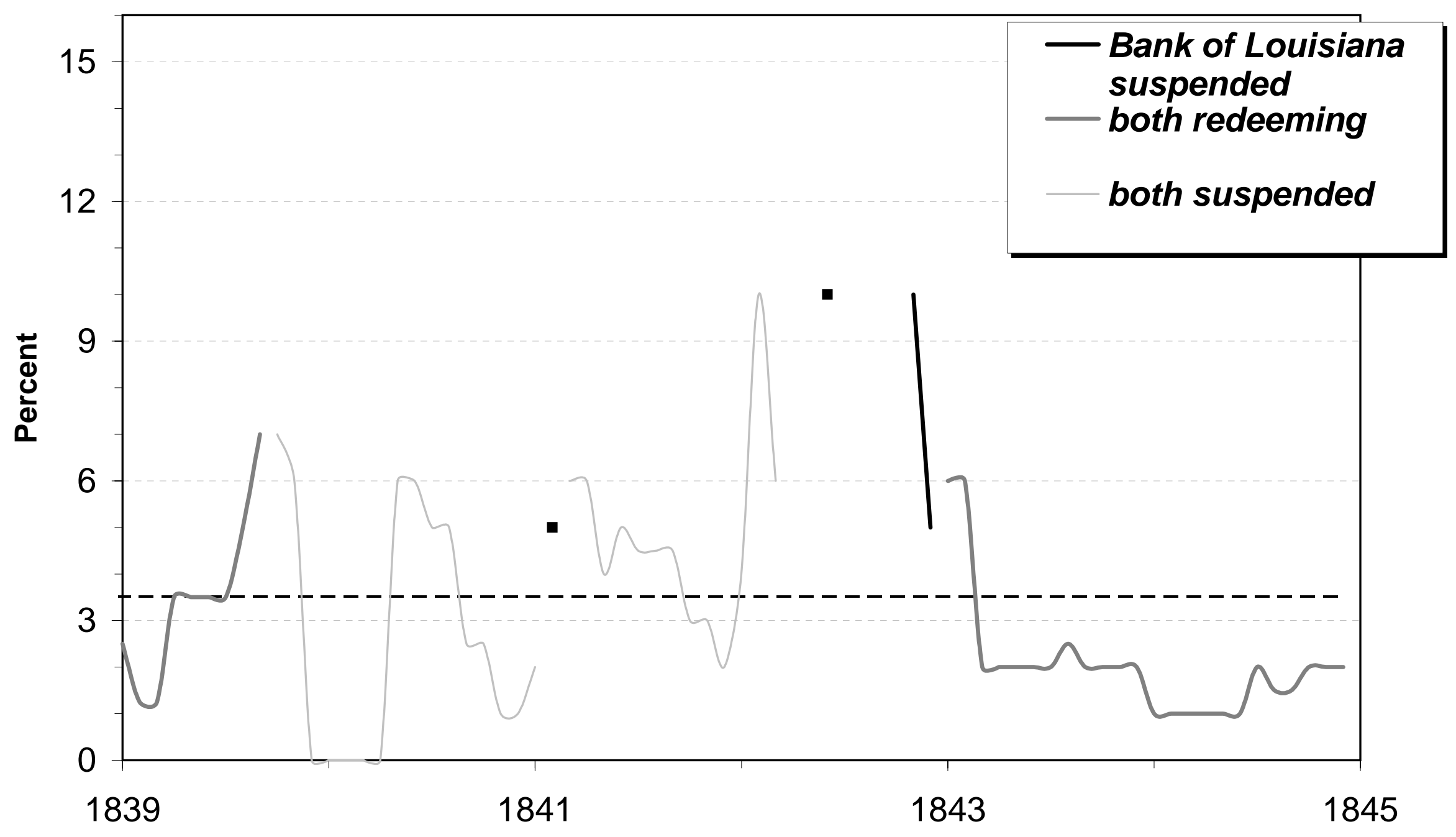


Figure 11: Discounts on notes of New York banks as quoted in Philadelphia, 1835 - 44

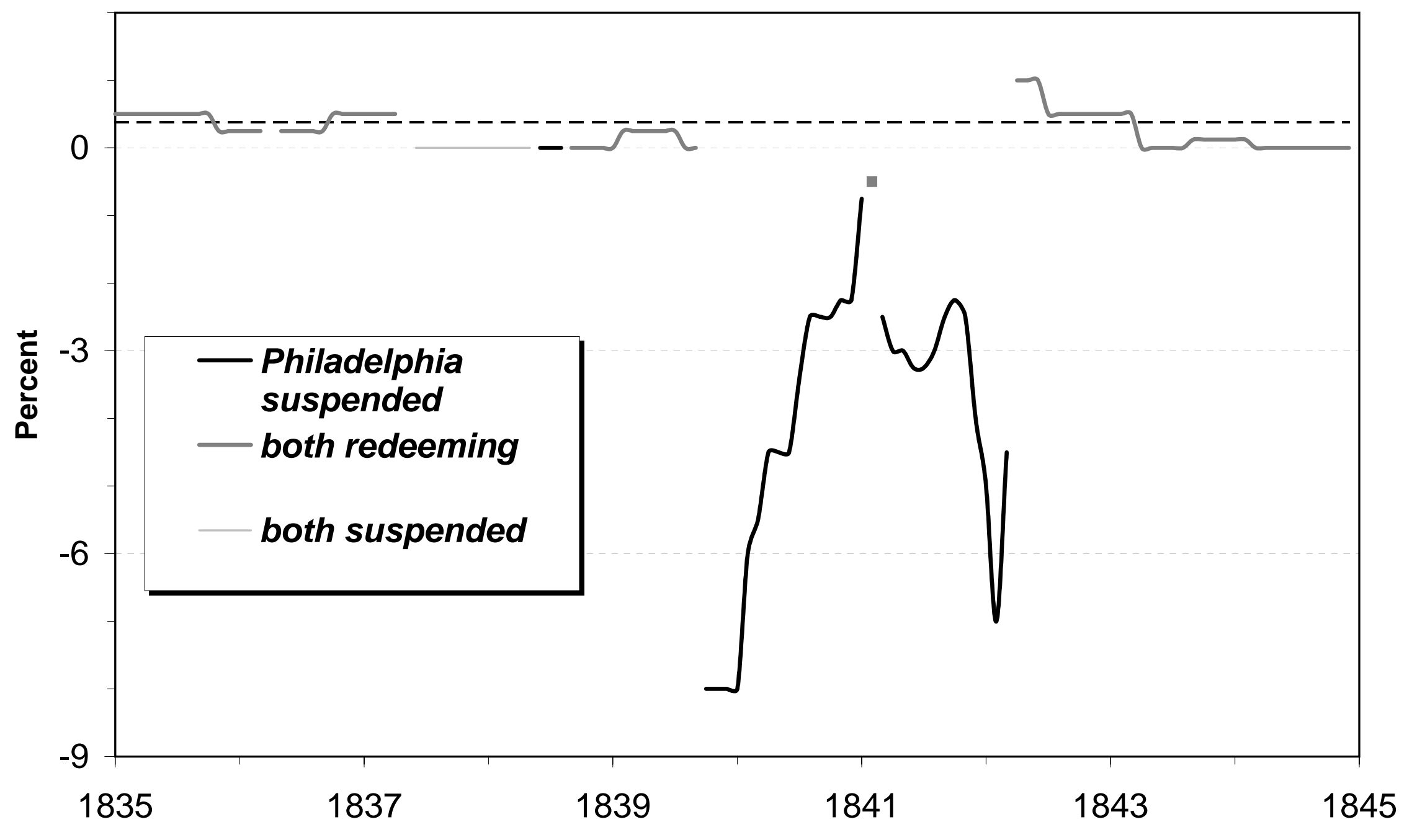


Figure 12: Discounts on notes of Charleston SC banks as quoted in Philadelphia, 1839 - 44

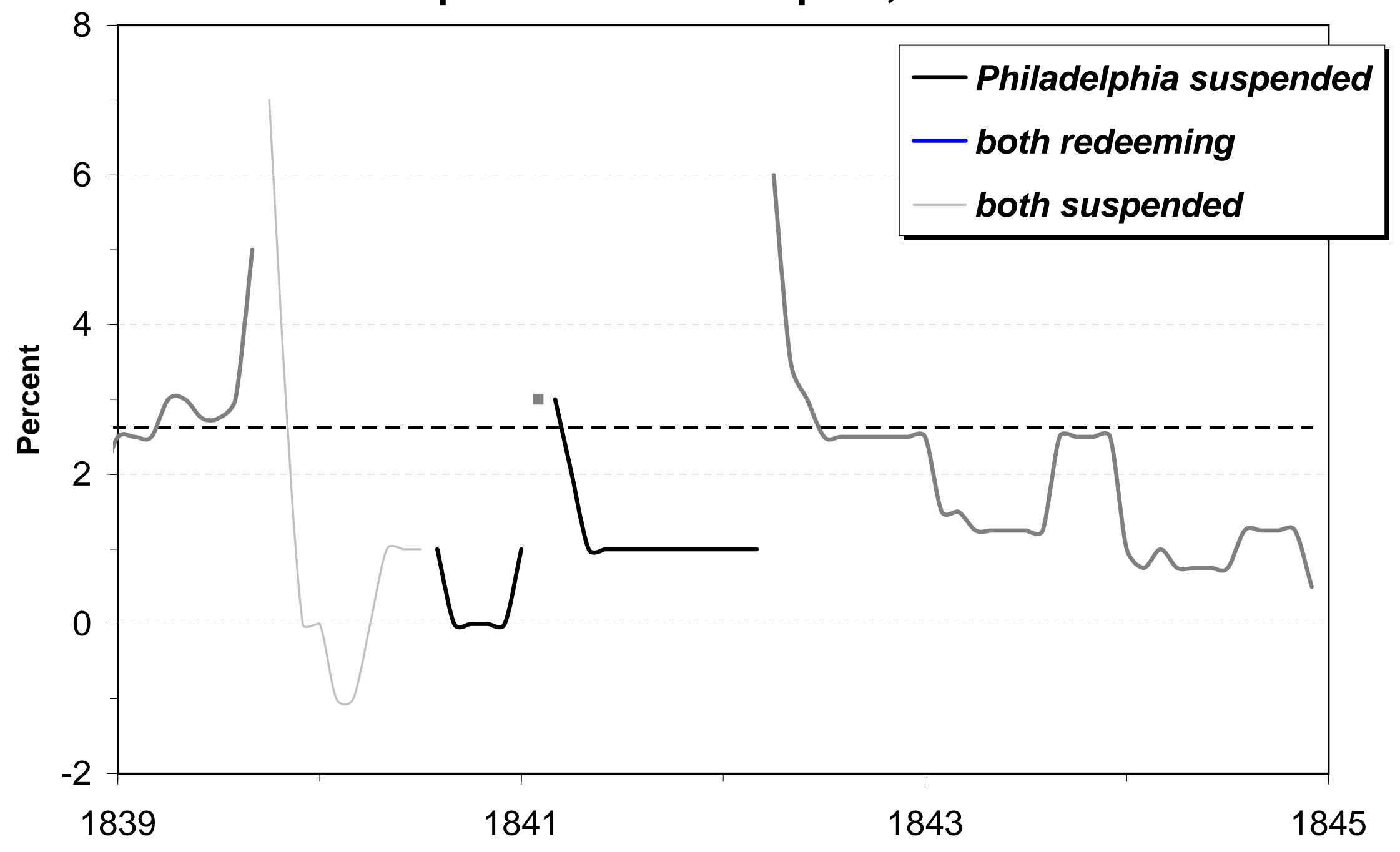


Figure 13: Discounts on banknotes in New York vs travel cost for 18 cities in 1847

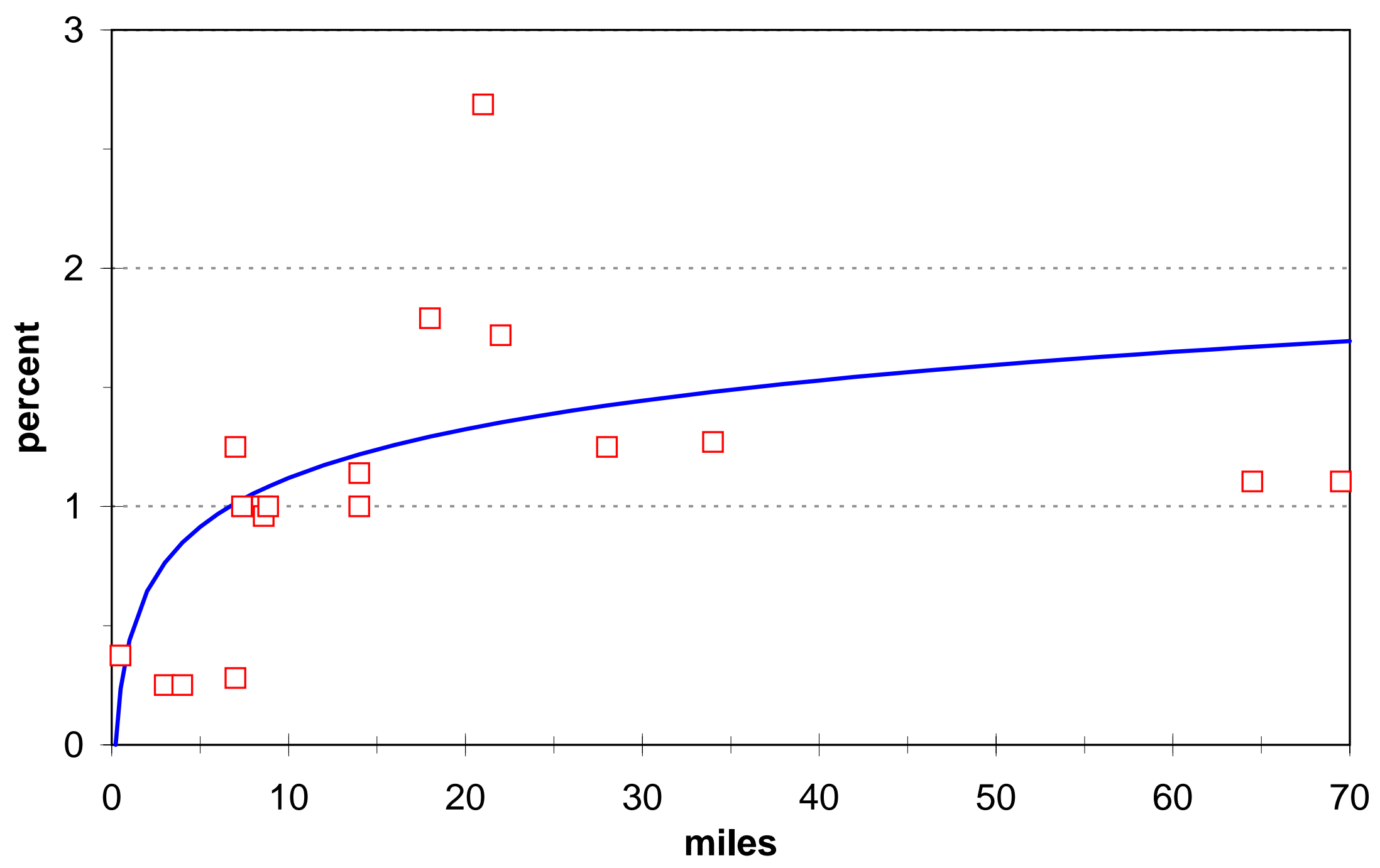


Figure 14: Discounts on banknotes in New York vs cost of travel for 26 cities in 1854

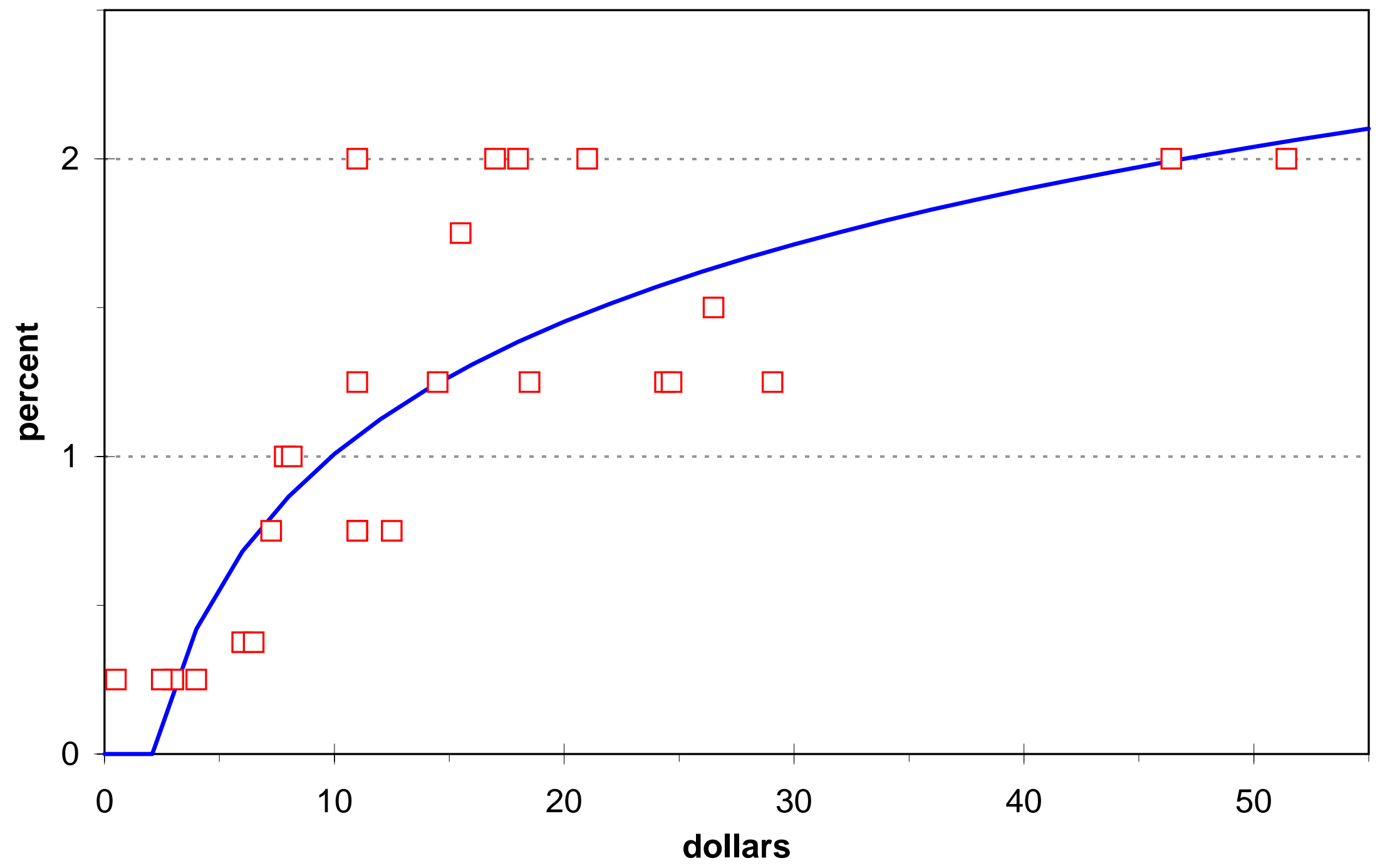


Figure 15: Discounts on banknotes in Philadelphia

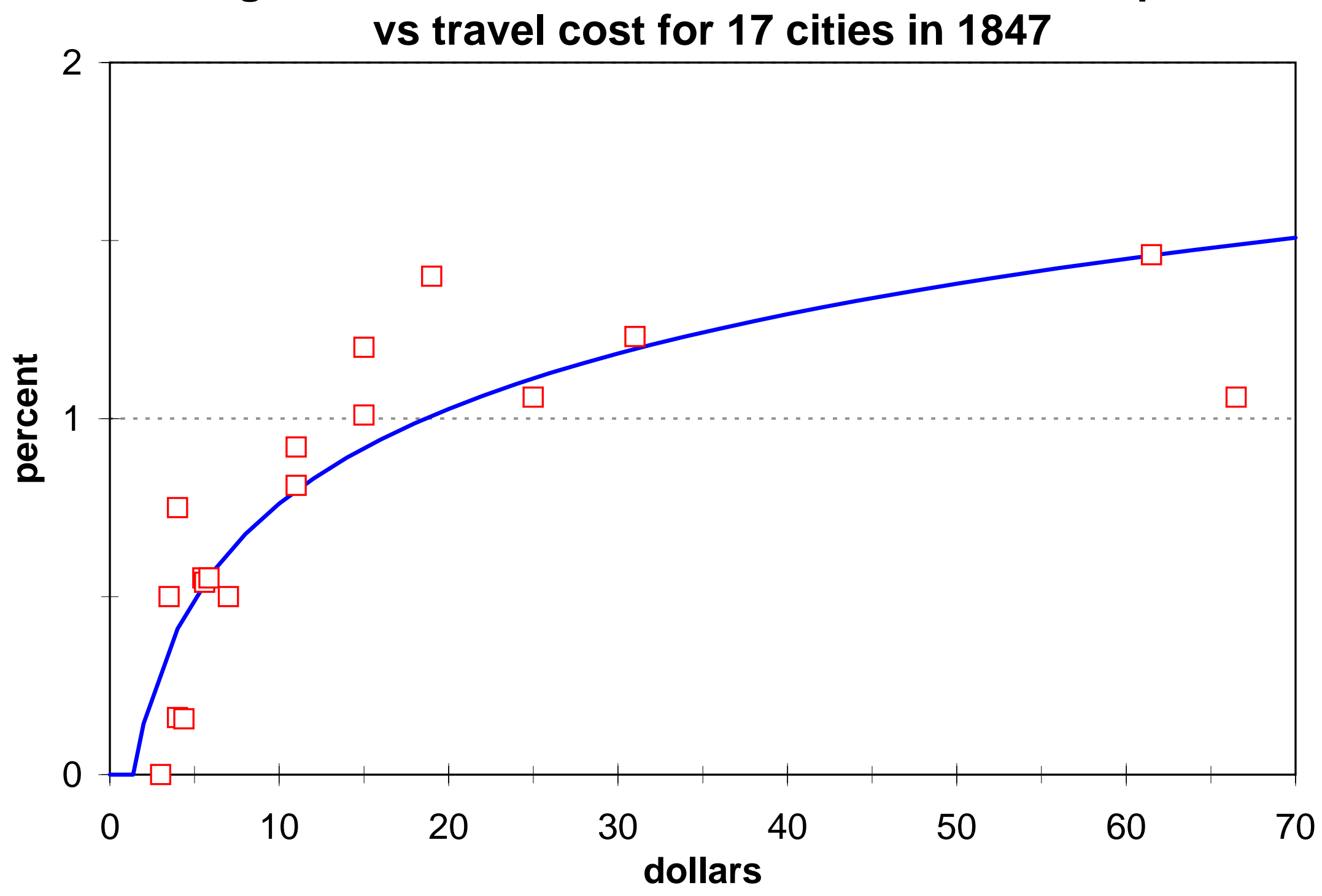


Figure 16: Discounts on banknotes in Philadelphia vs travel cost for 26 cities in 1854

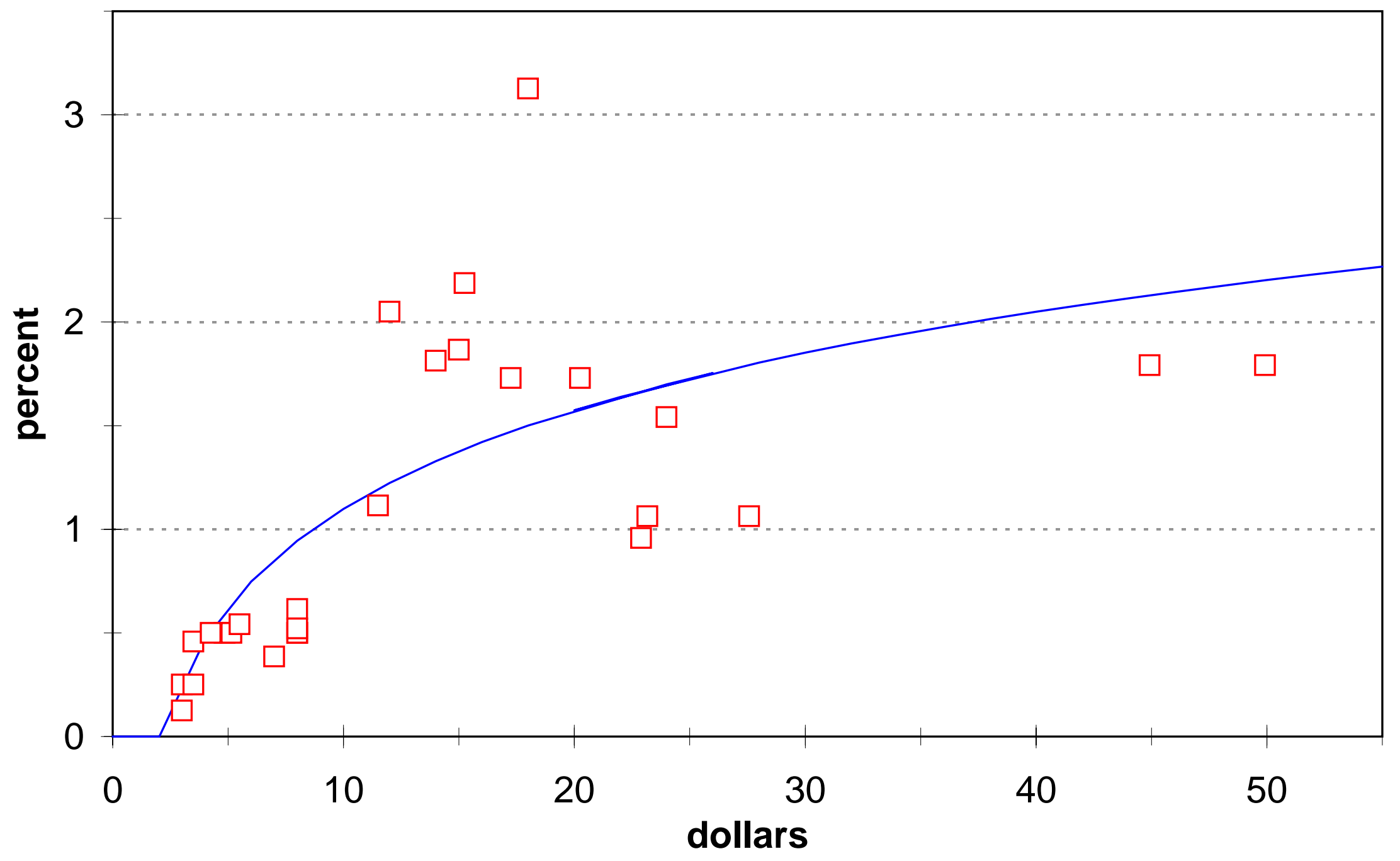


Figure 17: Discounts on banknotes in New York

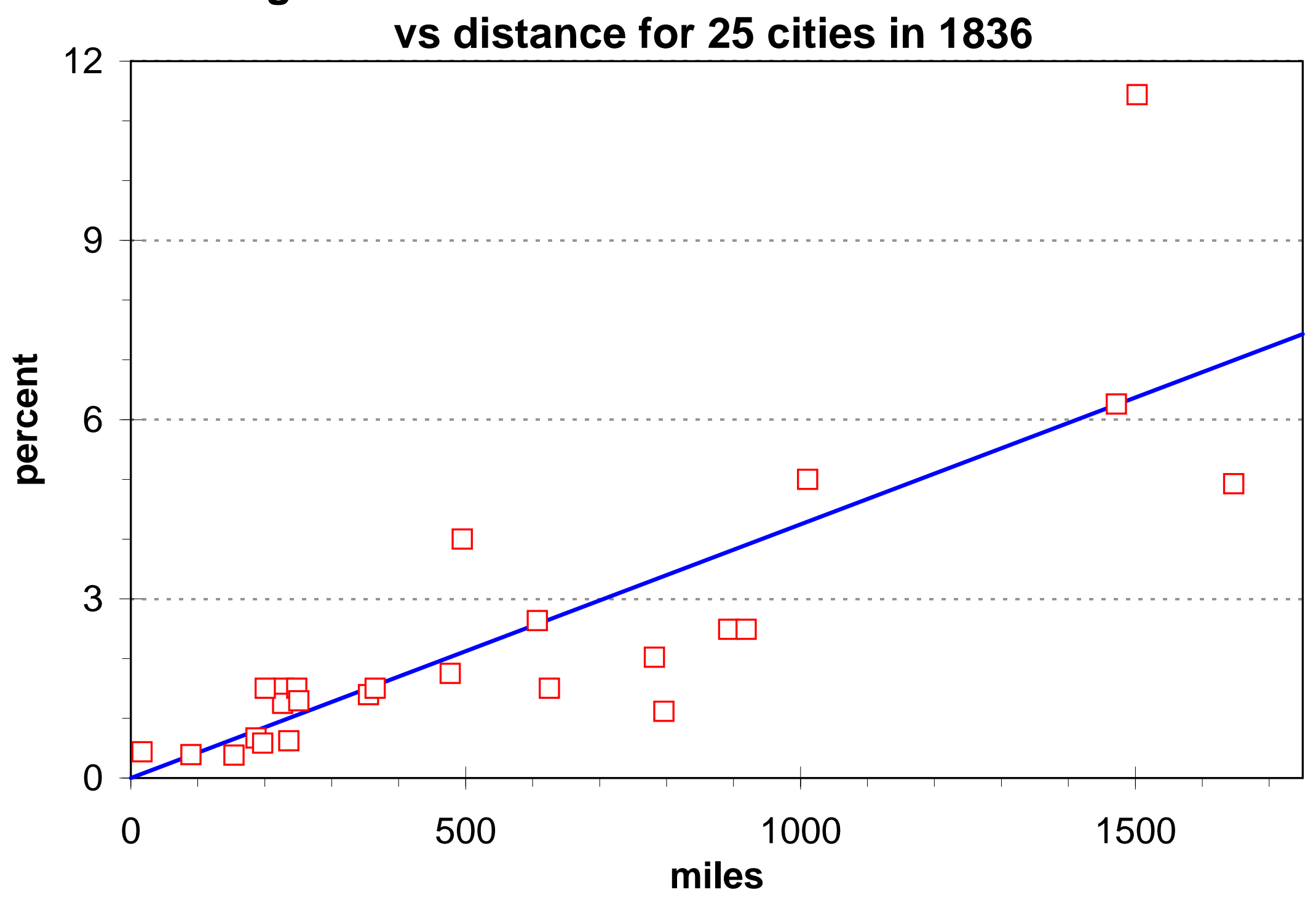


Figure 18: Discounts on banknotes in Philadelphia vs distance for 29 cities in 1836

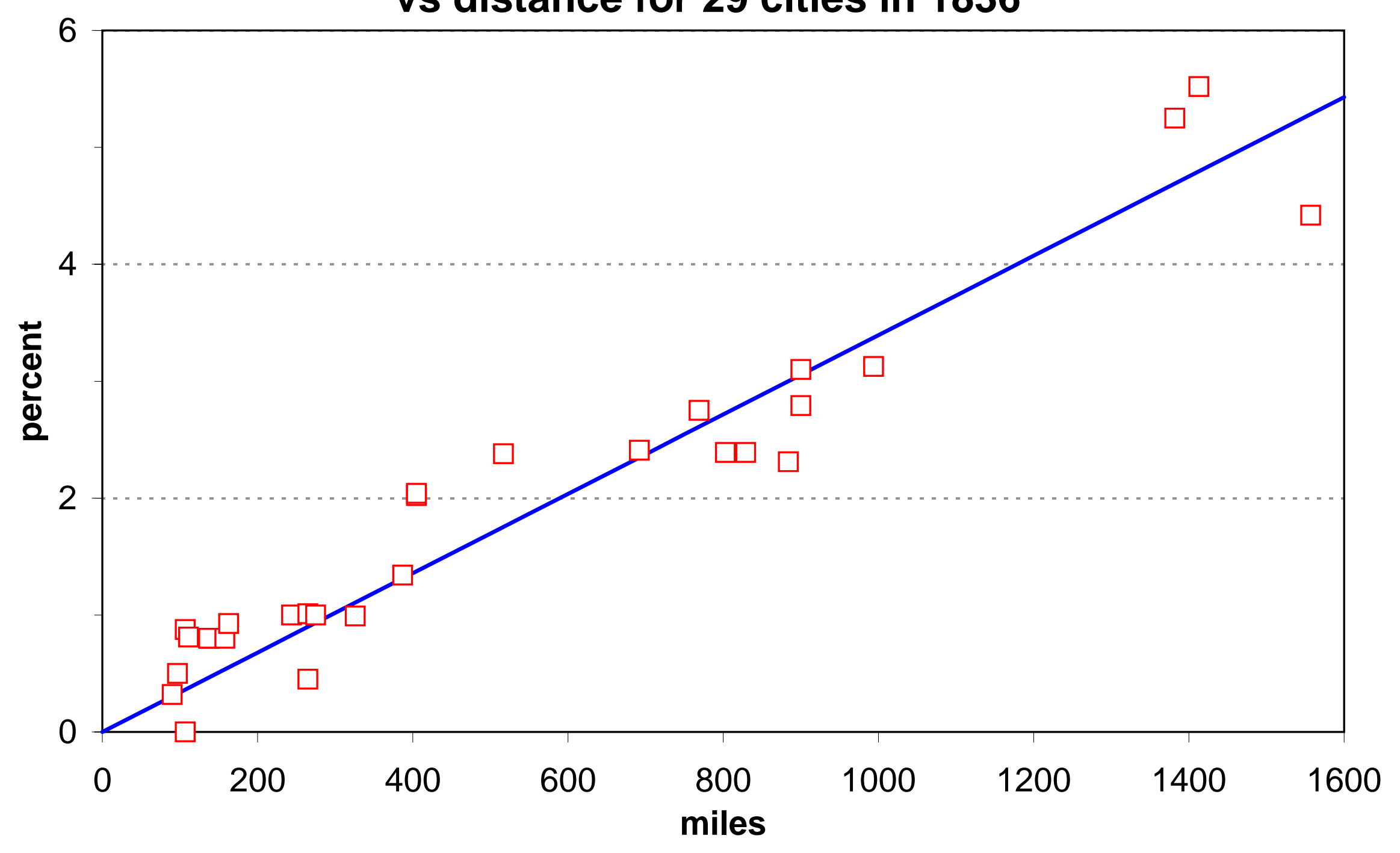


Table 1: Dates of bank suspensions and resumptions by location, 1837 - 1842

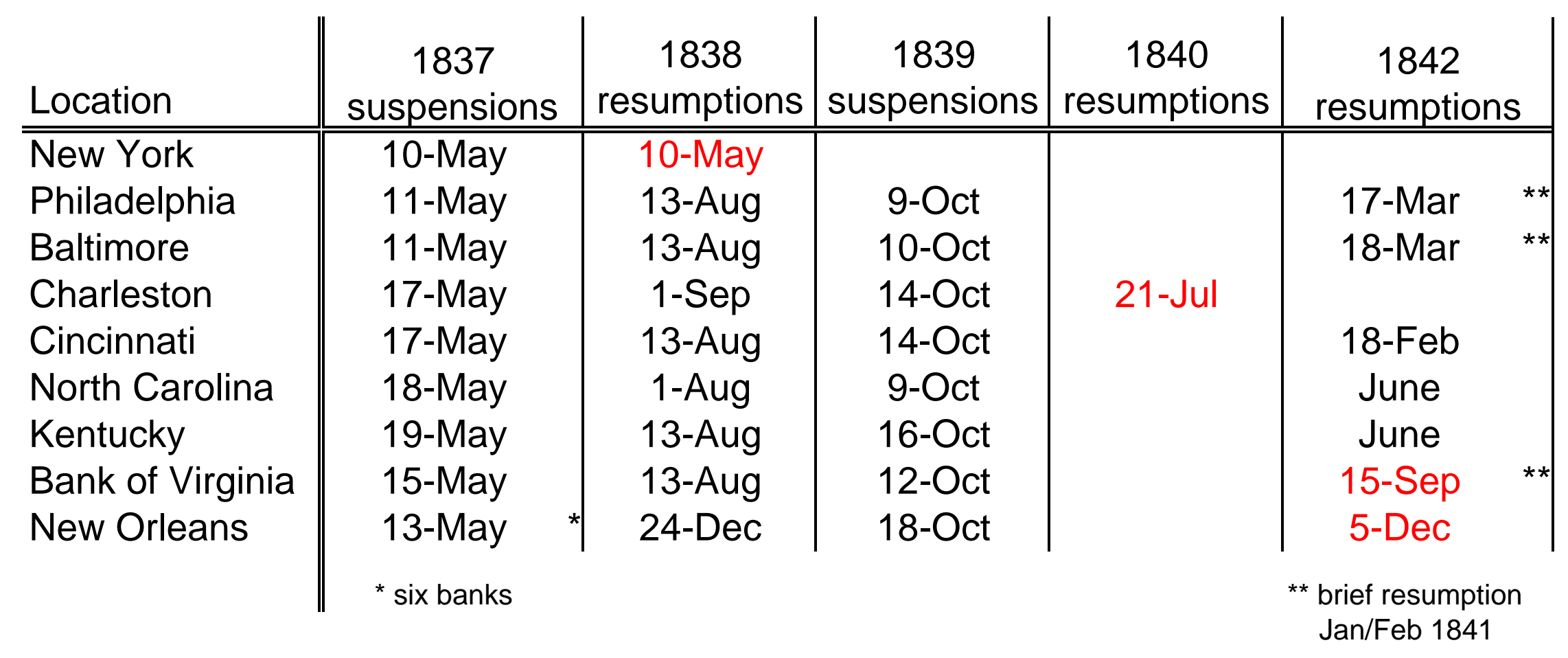


Table 2: Comparison of travel costs and discounts, 1854 with 1847

\begin{tabular}{|c|c|c|c|}
\hline $\begin{array}{l}\text { discount } \\
\text { smaller }\end{array}$ & $\begin{array}{c}\text { cost } \\
\text { smaller }\end{array}$ & $\begin{array}{c}\text { cost } \\
\text { same }\end{array}$ & total \\
\hline \multirow{4}{*}{$\begin{array}{l}\text { in } 1854 \\
\text { no change } \\
\text { in } 1847\end{array}$} & \multicolumn{3}{|c|}{ New York auotes } \\
\hline & 4 & & 7 \\
\hline & 1 & & 5 \\
\hline & 4 & & 5 \\
\hline \multirow{3}{*}{$\begin{array}{l}\text { in } 1854 \\
\text { in } 1847\end{array}$} & \multicolumn{3}{|c|}{ Philadelphia quotes } \\
\hline & 4 & & 9 \\
\hline & 4 & & 7 \\
\hline
\end{tabular}




\section{Appendix Table 1: Cost of One Way Travel from New York and Philadelphia to Various Locations, 1847 and 1854}

\begin{tabular}{lrr|rr} 
& \multicolumn{2}{c|}{ New York } & \multicolumn{2}{|c}{ Philadelphia } \\
Location & 1847 & 1854 & 1847 & 1854 \\
\hline \hline Boston, MA & 4.00 & 4.00 & 7.00 & 7.00 \\
Albany, NY & & 2.50 & & 5.50 \\
New York, NY & ---- & ----- & 3.00 & 3.00 \\
Paterson, NJ & 0.50 & 0.50 & 3.50 & 3.50 \\
Harrisburg, PA & 7.00 & & 4.00 & \\
Philadelphia, PA & 3.00 & 3.00 & ---- & ---- \\
Pittsburgh, PA & & 11.00 & & 8.00 \\
Annapolis, MD & 8.50 & 7.85 & 5.50 & 4.85 \\
Baltimore, MD & 7.00 & 6.00 & 4.00 & 3.00 \\
Cumberland, MD & 14.00 & 11.00 & 11.00 & 8.00 \\
Ellicotts Mills, MD & 7.38 & 6.50 & 4.38 & 3.50 \\
Frederick, MD & 8.85 & 8.15 & 5.85 & 5.15 \\
Washington, DC & 8.60 & 7.25 & 5.60 & 4.25 \\
Richmond, VA & 14.00 & 11.00 & 11.00 & 8.00 \\
Wheeling, VA & 18.00 & 14.50 & 15.00 & 11.50 \\
Wilmington, NC & 22.00 & 15.50 & 19.00 & 14.00 \\
Charleston, SC & 28.00 & 24.39 & 25.00 & 22.89 \\
Savannah, GA & & 29.07 & & 27.57 \\
Augusta, GA & 34.00 & 24.67 & 31.00 & 23.17 \\
Cleveland, OH & & 11.00 & & \\
Cincinnati, OH & & & & 15.00 \\
Louisville, KY & & 18.00 & & 17.25 \\
Lexington, KY & & 21.00 & & 20.25 \\
Detroit, Ml & 21.00 & 12.50 & & 12.00 \\
Indianapolis, IN & & 17.00 & & 15.25 \\
Chicago, IL & & 18.50 & & 18.00 \\
St.Louis. MO & & 26.50 & & 24.00 \\
Mobile, AL & 64.50 & 46.42 & 61.50 & 44.92 \\
New Orleans, LA & 69.50 & 51.42 & 66.50 & 49.92
\end{tabular}

